\title{
TRADITIONAL MEDICINAL PLANTS IN BEN EN NATIONAL PARK, VIETNAM
}

\author{
HOANG VAN SAM ${ }^{1,2}$, PIETER BAAS ${ }^{2} \&$ PAUL J.A. KEßLER ${ }^{3}$
}

\begin{abstract}
SUMMARY
This paper surveys the medicinal plants and their traditional use by local people in Ben En National Park, Vietnam. A total of 230 medicinal plant species (belonging to 200 genera and 84 families) is used by local people for treatment of 68 different diseases. These include species that are collected in the wild $(65 \%)$ as well as species grown in home gardens. Leaves, stems and roots are most commonly used either fresh or dried or by decocting the dried parts in water. Women are mainly responsible for health care, they have better knowledge of medicinal plants than men, and also collect them more than men at almost every age level. The indigenous knowledge of traditional medicinal plants may be rapidly lost because $43 \%$ of the young generation do not know or do not want to learn about medicinal plants, and the remainder knows little about them. Moreover, nowadays local people tend to use western medicine. Eighteen medicinal plant species are commercialized and contribute on average $11 \%$ to the income of the households. The majority of medicinal species are used by less than half of the households and $68 \%$ of the medicinal plant species have use indices lower than 0.25 . Only 6 of the medicinal species of Ben En are listed in the Red data list of Vietnam, but locally 18 medicinal species are endangered because of overharvesting.

A comparison of traditional uses of medicinal plants in Ben En National Park with traditional uses elsewhere in South-East Asia and the Indo-Pacific region shows that the same species may be used for widely different treatments by different ethnic groups.

The conservation, sustainable use and economic potential of medicinal plants is discussed. We argue that their use, cultivation in home gardens, and marketing should be encouraged as an affordable alternative to expensive western medicine.
\end{abstract}

Key words: Ben En National Park, traditional medicinal plants, disease treatment, conservation.

\section{INTRODUCTION}

Man is known to have utilized plants as a source of medicinal drugs for thousands of years. Medicinal plants are potential sources of new drugs and hold a great value for developing pharmaceutical products, phytomedicines, and dietary supplements (King et al. 1999).

An effective way to find new drugs is to follow the indigenous knowledge on medicinal plants (Spjut \& Perdue 1976, Mendelsohn \& Balick 1995, Swerdlow 2000).

1) Forest Plant Department, Vietnam Forestry University, Xuan Mai, Hanoi, Vietnam; e-mail:samfuv@gmail.com.

2) Nationaal Herbarium Nederland, Leiden University branch, P.O. Box 9514, 2300 RA Leiden, The Netherlands; e-mail: baas@nhn.leidenuniv.nl.

3) Hortus botanicus Leiden, P.O. Box 9516, 2300 RA Leiden, The Netherlands; e-mail: prefect@ hortus.leidenuniv.nl. 
Using ethnobotany to identify promising plants could substantially reduce the costs for developing at least some pharmaceutical drugs (Mendelsohn 1997). About 80\% of the world's population relies on traditional medicine (Farnsworth et al. 1985). Especially in remote areas in developing countries, medicinal plants may form the only available source of health care (Kasparek et al. 1996, Van Andel 2000).

Vietnam is no exception to this phenomenon. The better hospitals are all located in Hanoi, Ho Chi Minh City, and in other main cities. The health care situation in the research area of Ben En National Park is generally much less favourable. The few hospitals and health centres in the interior are often ill-equipped and suffer from lack of trained staff. Only few people can afford to travel to the hospital in the city when they need medical assistance, instead of seeking treatment in local health centres. Most local people do not have health insurance. The majority of the health problems of the local people in Ben En National Park are related to stomach ache, malaria, diarrhoea, wounds, and common colds.

Knowledge of medicinal plants, as once embedded in numerous indigenous cultures, is rapidly disappearing. Year by year, the total sum of human knowledge about the species, distribution, ecology, management, and extraction of medicinal plants is declining: the continuation of a process of loss of local cultural diversity that has been underway for centuries (Hamilton 2003). Although in many communities medicinal plants are the only available source for medical treatment, local indigenous remedies are less used now than before. In many tropical regions indigenous knowledge is at risk of extinction just as is biodiversity itself (Slikkerveer 1999, Van Andel 2000).

Ethnobotanical research can play a key role in the revitalization and revaluation of indigenous knowledge (Martin 1995). For Ben En National Park in particular very few ethnobotanical data exist. Some research has been conducted on biodiversity (Tordoff et al. 2000), and one study just listed plant or animal species, unfortunately without voucher specimens for scientific scrutiny (Anonymous 2000).

To analyse the role of medicinal plants in the indigenous communities in Ben En National Park, this study deals with the variety of medicinal plants and their uses recorded during a one year survey of non-timber forest products in that region.

The main research questions with regard to the use of medicinal plants were:

- Which plant species are being used for which disease?

- Which medicinal plant species are being commercialized in the research area?

- What is the present role of medicinal plants in the health care system of the indigenous communities?

- How does the situation in Ben En National Park compare with other local communities depending on natural forest resources in and beyond Vietnam?

We hope that the documentation of this medicinal plant knowledge contributes to the conservation of both cultural diversity and plant biodiversity in Vietnam in general and Ben En National Park in particular. By compiling and spreading this knowledge we hope to achieve that other ethnic groups in the region benefit from these local and cheap resources. 


\section{METHODOLOGY}

Household surveys and interviews were carried out in 45 randomly selected households per village (out of a total of about 110-150 households per village). The standard interviews contained specific questions on age, gender, and ethnic background of the gatherers and main users of plant products. Additionally we used the 'walk-in-the-wood' method (Prance et al. 1987), to determine which products are harvested (and for what purpose) in the forests surrounding the villages. These trips were also used to collect voucher specimens for reliable identification of the harvested plants. Special collecting trips were organized with indigenous experts, e.g., traditional doctors, village elders and other local people who knew about medicinal plants. There are five traditional doctors (four females and one male) in the research area. Local names were also being noted during these surveys. Most information was confirmed by other informants. The information was also checked and compared with the 'Vietnam medicinal plants' (Loi 1995), 'Dictionary of medicinal plants of Vietnam' (Chi 1996), 'Plants of Vietnam' (Ho 2000), and the ProseA (Plant Resources of South-East Asia) Handbooks on 'Medicinal and poisonous plants' (De Padua et al. 1999, Van Valkenburg \& Bunyapraphatsara 2001, Lemmens \& Bunyapraphatsara 2003).

Market inventories were used to determine the price of the forest products that are for sale. These surveys served as an independent way to determine which products are harvested from the surrounding forest, and to assess local uses of these forest products.

All plants that were considered by local people to have medicinal properties were collected and identified. These plants not only included wild species but also cultivated plants and wild plants that had been taken from the forest and planted in gardens or agricultural fields. Botanical specimens were collected of all useful plants. One voucher of each specimen was deposited at the herbarium of the Vietnam Forestry University, additional vouchers were sent to the National Herbarium of the Netherlands and various specialists for identification.

The importance of medicinal plant species was identified using standard Participatory Rural Appraisal (PRA) techniques (PID \& NES 1989, Ngai 2001) where local people were asked to rank a list of regularly used local medicinal plants. The importance of medicinal plants for health care was determined using two criteria: 1) proportion of local people using each listed species; and 2) frequency of use. The importance of medicinal plant species for income generation was determined by calculating the income from each listed species for the local population.

The database resulting from the ethnobotanical inventory was used to calculate a use index (UI) for each species by using the following equation:

$$
\mathrm{UI}=\mathrm{U}_{\mathrm{s}} / \mathrm{N}
$$

Where $U_{s}$ is the number of households which mentioned a use for species $s ; \mathrm{N}$ is the total of households that were interviewed in the research area. This Use Index is a modification from the Use Value (UV) introduced by Phillips \& Gentry (1993) and recently used by De Lucena et al. (2007), which is calculated from the relative number of times a species is mentioned by various informants in ethnobotanical inventories. 
The market demand, intensity of collection, and abundance in the wild were classified as follows:

\section{Market demand}

- High: easy to sell in large amounts.

- Medium: Difficult to sell in large amounts.

- Low: only in very small supply on the market and sometimes left unsold because the demand was not stable.

\section{Collection intensity}

- High: local people collect the plants in large amounts because of high demand of the market and/or for personal use.

- Medium: the collected amount is not big because the demand is not high, plants are not abundant, or it is difficult to collect them in large amounts.

- Low: the demand of the market is low or non-existent. People mainly collect for home consumption, but in small amounts.

\section{Abundance in the wild}

- High: the species is easy to find and abundant.

- Medium: the species is neither abundant nor rare.

- Low: the species is rare, and although local people can find it with special effort, the species will be endangered if collection continues.

\section{STUDY AREA}

Field work was conducted in Ben En National Park $19^{\circ} 30^{\prime}$ to $19^{\circ} 40^{\prime} \mathrm{N}$ by $105^{\circ} 21^{\prime}$ to $105^{\circ} 35^{\prime} \mathrm{E}$, situated in the Nhu Thanh and Nhu Xuan districts of Thanh Hoa province, Vietnam (Fig. 1). The highest peak is about $490 \mathrm{~m}$. The core zone of the National Park

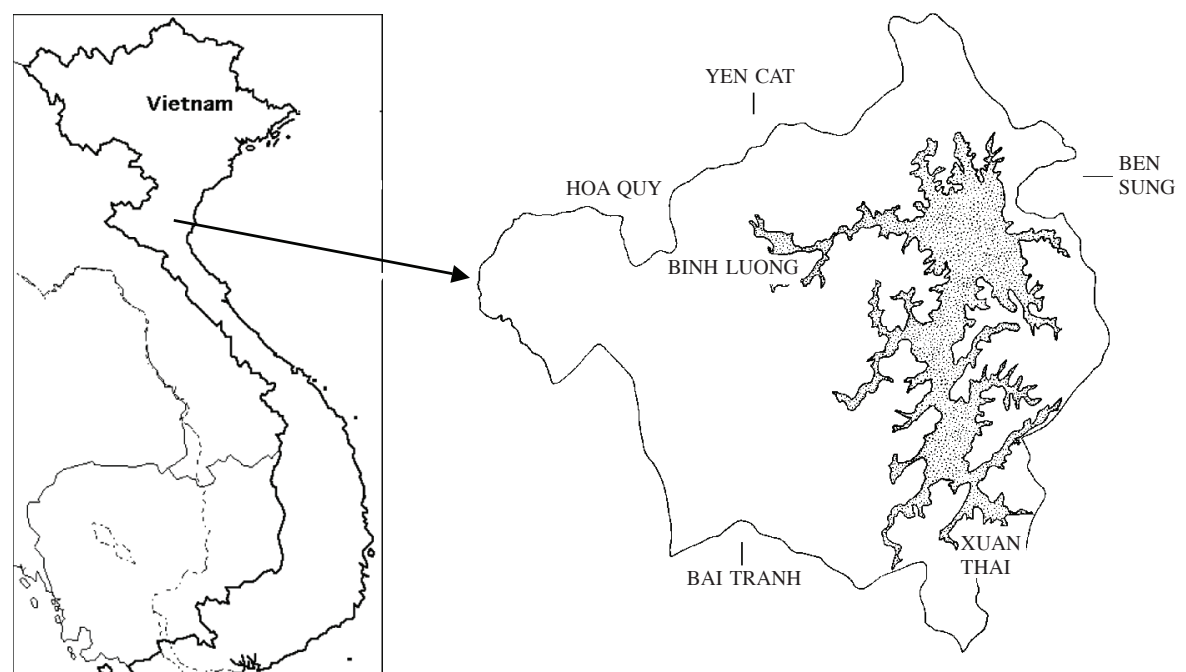

Fig. 1. Map of Ben En National Park in Vietnam (lakes are dotted). Methodology. 
covers 15,800 ha, while the buffer zone covers around 12,000 ha. About 18,000 people live in the buffer and core zones of the National Park (Tordoff et al. 2000). The majority of the people living in the national park belong to the Kinh, Thai, Muong, and Tay ethnic groups, although there are also a small number of Tho people. The interviews were carried out in three villages: Xuan Thai, Binh Luong, and Hoa Quy. Additional information on medicinal plants was collected in the markets of Ben Sung and Yen Cat. The vegetation of the core zone is dominated by disturbed tropical evergreen rain forest, which has been affected by human activities, especially logging, which was legal until the park was established in 1991, but has continued illegally up to now. A full account of the vegetation and plant species diversity in the Park will be published in the near future (Hoang et al. in prep.).

\section{RESULTS}

\section{Diversity of medicinal plants}

A total of 230 medicinal plant species were used by local people in Ben En National Park belonging to 200 genera and 84 families. These species were involved in 313 different treatments and recipes. For most species only one recipe was mentioned; some have multiple medicinal applications. A complete list of species and their local medicinal uses is given in Appendix 1. The total number of vascular plant species in the Park is about 1390 (Hoang et al. 2008).

Most of the medicinal plant species in Ben En National Park are angiosperms, only 2 species belong to the gymnosperms and 9 species are ferns. Sixteen percent of all plant species in the Park are used by local people for medicinal purposes. The number of medicinal plant species used by local people in Ben En National Park is $7.2 \%$ of the total medicinal plant species in Vietnam (Chi 1996). Diversity of taxa is shown in Table 1.

Among the 84 families, the top 10 families with the highest number of medicinal species in the area are listed in Table 2.

From the 230 species of medicinal plants recorded in Ben En National Park 65\% of the species were collected from the wild. These were all plants naturally occurring in different vegetation types (primary, secondary and logged-over forests, shrubbery, along roads, along streams, and in agricultural fields). Twenty percent of the species were cultivated in home gardens or in fields or even along the village road. This practice helps to develop the medicinal plant resources, and also makes them more widely available, especially when derived from rare and endangered species. Fifteen percent

Table 1. Diversity of taxa.

\begin{tabular}{lccc}
\hline & $\begin{array}{l}\text { Number of } \\
\text { medicinal species }\end{array}$ & $\begin{array}{l}\text { Total number of } \\
\text { plant species in Ben En }\end{array}$ & $\begin{array}{l}\text { Percentage of medicinal } \\
\text { species/total species in Ben En }\end{array}$ \\
\hline Ferns & 9 & 86 & 10 \\
Gymnosperms & 2 & 9 & 22 \\
Angiosperms & 219 & 1294 & 17 \\
Total & 230 & 1389 & 16 \\
\hline
\end{tabular}


Table 2. The 10 families with the highest numbers of medicinal species.

\begin{tabular}{lcc}
\hline Name of family & Number of genera & Number of species \\
\hline Euphorbiaceae & 9 & 11 \\
Asteraceae & 8 & 9 \\
Moraceae & 5 & 9 \\
Fabaceae & 8 & 8 \\
Rubiaceae & 7 & 8 \\
Menispermaceae & 6 & 8 \\
Verbenaceae & 4 & 8 \\
Rutaceae & 5 & 7 \\
Araceae & 6 & 6 \\
Apocynaceae & 6 & 6 \\
\hline
\end{tabular}

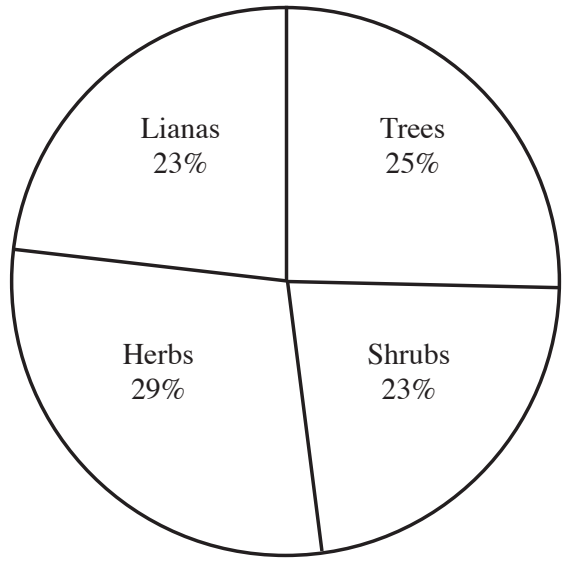

Fig. 2. Percentage of life forms of medicinal plants species used in Ben En National Park.

Table 3. Diverse parts of medicinal plants used by local people.

\begin{tabular}{lcc}
\hline Parts of plant & Number of species & Percent of total \\
\hline Leaves & 141 & 61 \\
Root, rhizome & 96 & 42 \\
Stem & 64 & 28 \\
Bark & 26 & 11 \\
Fruit & 19 & 8 \\
Whole plant & 14 & 6 \\
Seed & 9 & 4 \\
Flower & 9 & 4 \\
Tuber & 8 & 3 \\
Bulb & 3 & 1 \\
Latex & 2 & 1 \\
\hline
\end{tabular}


of the species were both taken from the forest, and also grown in the home gardens and agricultural fields. This semi-domestication reduces the need to cover long distances in the forest to search for plants.

\section{Diversity of life forms of medicinal plants}

The analysis of the life forms of medicinal plants used by local people in Ben En National Park is shown in Fig. 2. Herbaceous medicinal plants used by local people usually grow on the forest floor, along forest edges and roads, in fields and villages. They are mainly Amaranthaceae, Araceae, Asteraceae, and Zingiberaceae. Next in order of importance are forest trees mainly belonging to Euphorbiaceae, Moraceae, Rubiaceae, and Rutaceae. The smallest groups are formed by lianas and shrubs belonging to mainly Araceae, Asclepiadaceae, Cucurbitaceae, Menispermaceae, and Smilacaceae. Shrubs growing in the forest or along streams mainly are Myrtaceae and Solanaceae.

\section{Diversity of plant parts used}

In traditional medicine, different plant parts are used to treat different diseases: different components of one medicinal plant may have different effects. Some medicinal plant species have only one component that can be used, while for other species several components or the whole plant can be used. Of the identified medicinal plants in the research area, the whole plant is used of 14 species, whereas one species provides four useful components, 32 species provide three, 98 species provide two, and 85 species provide one component.

The diversity of parts used is indicated in Table 3. Leaves are most commonly used, either fresh or dried. Stems and roots are also common, either fresh or by decocting the dried root in water. Stems are usually chopped into small pieces and decocted in water. Often, different parts of the plants are combined to treat a disease.

\section{Diseases treated with medicinal plants}

The 230 medicinal plants species in Ben En National Park were used for treatment of 68 different diseases. For 20 of these diseases local people use only one medicinal plant for each disease. For example cancer was treated only with Clausena lansium (Rutaceae), mumps were exclusively treated with Momordica cochinchinensis $(\mathrm{Cu}-$ curbitaceae), diabetes with Aralia touranensis (Araliaceae), aphasia with Zanthoxylum avicennae (Rutaceae), paralysis with Alangium chinense (Alangiaceae), and abscesses with Hodgsonia macrocarpa (Cucurbitaceae). For 12 of the 68 diseases local people used two plant species for treatment of each disease. For example, risk of miscarriage was treated with roots of Boehmeria nivea (Urticaceae) or with stems and leaves of Artemisia vulgaris (Asteraceae), and constipation was treated with leaves of Cuscuta chinensis (Cuscutaceae) or leaves of Desmos cochinchinensis (Annonaceae). For 5 diseases local people used three plant species for treatment of each disease. For example, impotence was treated with roots of Morinda officinalis (Rubiaceae), roots of Morinda citrifolia (Rubiaceae), or leaves and seeds of Allium odorum (Alliaceae).

The highest number of species was used to treat fairly common diseases, such as common colds, stomach ache, dysentery, weakness, itches, and diarrhoea (see Fig. 3). 


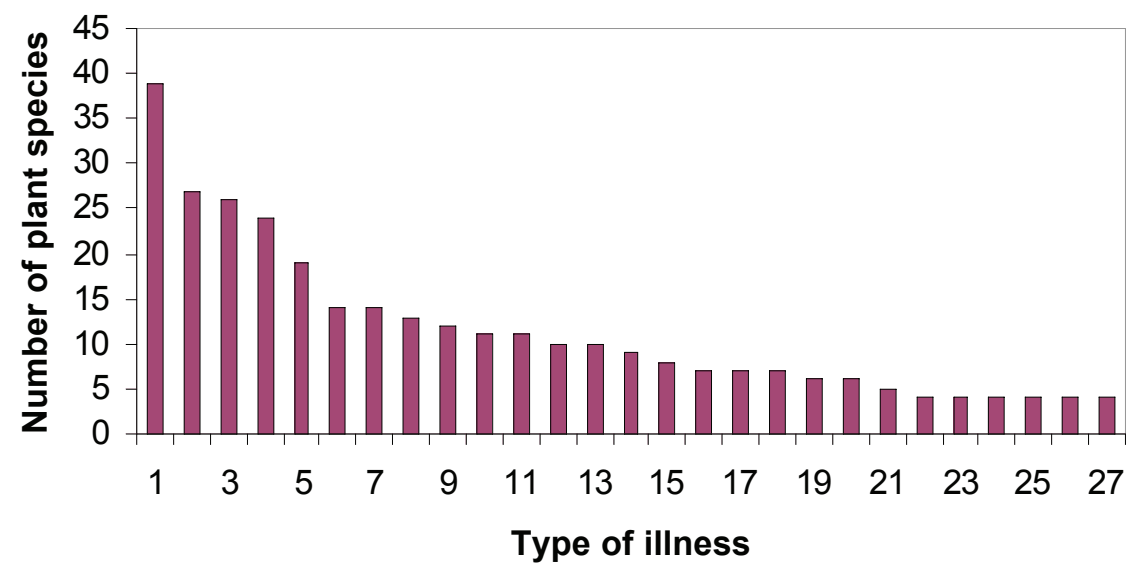

Fig. 3. Number of plant species used for different symptoms or illnesses in Ben En National Park. $1=$ Common colds; $2=$ stomach ache; $3=$ dysentery; $4=$ weakness; $5=$ itches; $6=$ indigestion; $7=$ diarrhoea $; 8=$ malaria; 9 = wounds; $10=$ snakebites; $11=$ fever $; 12=$ toothache; $13=$ haemostatic; $14=$ rheumatism; 15 = bone fractures; $16=$ irregular menses; $17=$ high blood pressure; $18=$ arthritis; $19=$ sores $; 20=$ infection; 21 = urinating problems; $22=$ sore throat $; 23=$ skin diseases $; 24=$ oedema; $25=$ haemorrhage $; 26$ = detoxification; $27=$ burns.

Seven of the most common diseases in the research area are discussed below.

Wounds and cuts

Wounds and cuts can be caused by many agents, for instance spiny lianas, leaves of some grasses, and sharp limestone edges when people walk in the forest, and by knives, scissors, and other sharp utensils. Cuts soon become infected and may develop into deeper wounds and even skin sores. Common treatments include crushing or chewing leaves and covering cuts with them. Some plant species are commonly used for treatment of cuts and wounds, such as the leaves of Piper betle (Piperaceae) and leaves of Microsorum superficiale (Polypodiaceae), and leaves of Eclipta prostrata (Asteraceae).

\section{Stomach ache}

Stomach ache can be a symptom of many kinds of disease. Large numbers of medicinal plants are used against it, but only few species were said to cure the complaints completely. The Thai, Tho, and Muong ethnic groups are often quite knowledgeable on the collection and preparation of anti stomach ache plants and actively exchange recipes with other ethnic groups in the region to combat the symptoms. Medicinal plants which are used for the treatment of stomach ache are for example leaves of Eupatorium odoratum (Asteraceae), leaves of Ardisia silvestris (Myrsinaceae) or rhizomes of Curcuma zedoaria (Zingiberaceae).

\section{Diarrhoea}

Diarrhoea is associated with several diseases, mostly attributable to poor sanitary practices and infected drinking water. The local people in Ben En National Park prefer to drink rain water rather than boiled water. In the dry season, there is little choice, and 
water from Muc Lake (the lake inside the National Park) and streams is used. Many people get diarrhoea in this season. Barks, roots and leaves decoctions are specifically used to treat diarrhoea. Celosia cristata (Amaranthaceae) treatment was said to be effective against diarrhoea with blood, which indicates bacterial dysentery. Leaves of Eupatorium odoratum (Asteraceae), bark of Melia azedarach (Meliaceae), and bark of Ficus auriculata (Moraceae) are just three examples of plant species used against diarrhoea in general.

\section{Snakebites}

Naja naja, Bugarus fasciatus, and Ptyas korros are dangerous, poisonous snakes in Ben En National Park. When a person is bitten, the bite can be deadly within hours. The roots and leaves of Gnetum montanum (Gnetaceae), the leaves of Phyllanthus urinaria (Euphorbiaceae), and leaves and stems of Gynura crepidioides (Asteraceae) are considered to be the most effective medicinal plants to cure snakebites. The skin is sliced open, and some of the crushed or chewed plant parts are applied to the wound. This treatment must be applied as soon as possible after the bite.

\section{Risk of miscarriage}

Some medicinal plant species are used to prevent miscarriages. In the research area, pregnant women drink an extract from the leaves and stems of Artemisia vulgaris (Asteraceae), mixed with some salt or sugar. Another species said to be effective to prevent miscarriages is Boehmeria nivea (Urticaceae): boiled roots of this species are eaten during pregnancy. Muong and Tho ethnic groups claim that the older the roots, the better the effects.

\section{Weakness}

Weakness can be caused by insomnia, after giving birth or by excessive fatigue. A total of 24 plant species was used to treat weakness. Most remedies consist of a decoction of leaves and stems that is boiled and drunk as tea, such as a decoction of the stems of Mucuna pruriens (Fabaceae), decoction of leaves and stems of Leonurus sibiricus (Lamiaceae), or the whole plant of Marsilea quadrifolia (Marsileaceae) are used to treat insomnia. Some plants are specially used by women after childbirth, such as the leaves of Artemisia vulgaris (Asteraceae), roots and stems of Jasminum subtriplinerve (Oleaceae), or the roots of Polygonum multiflorum (Polygonaceae), and the stems of Spatholobus suberectus (Fabaceae). After sickness or exhaustion local people use the flowers of Telosma cordata (Asclepiadaceae), or a decoction of the roots and stems of Fibraurea recisa (Menispermaceae).

\section{Common colds}

A total of 39 plant species was used to treat common colds. Most remedies consisted of a decoction of leaves, which was boiled and drunk as tea; some plant species are drunk after grinding them together with sugar or salt and a little water. Some plants are specifically used to treat children's colds such as the leaves of Allium odorum (Alliaceae), and the leaves of Ocimum tenuiflorum (Lamiaceae). Some plant species could treat most kinds of colds, such as the leaves of Blumea balsamifera (Asteraceae), the bulbs of Allium sativum (Alliaceae), or leaves and roots of Glycosmis pentaphylla (Rutaceae). Pneumonia was clearly distinguished from the common colds and treated differently. 


\section{Collection and preparation of medicinal plants}

Who is collecting medicinal plants?

From interviewing households and key informants, it emerged that women collect medicinal plants more than men at almost every age level, especially in the age classes of over 26 years old. This indicates that women are mainly responsible for health care. From the completed questionnaires it was also evident that women have a better knowledge of medicinal plants than men. Young people are rarely engaged in collecting medicinal plants (Table 4).

Table 4. Percentage of gender and age level of local people in Ben En National harvesting medicinal plants.

\begin{tabular}{llc}
\hline Age & Gender & $\begin{array}{c}\text { Percentage of individuals } \\
\text { collecting medicinal plants }\end{array}$ \\
\hline$>50$ & Male & 18 \\
& Female & 29 \\
$26-50$ & Male & 17 \\
& Female & 27 \\
$16-25$ & Male & 3 \\
& Female & 4 \\
$<16$ & Male & 1 \\
& Female & 1 \\
Average \% of males $=39$ & \\
Average $\%$ of females $=61$ & \\
\hline
\end{tabular}

\section{Knowledge of plants and preparation}

Most of the people interviewed were familiar with the species used for the treatments of common ailments like cold/cough, fever, headache, indigestion, itches, and plant remedies were used on a regular basis. As in other rural communities (On 2003) common knowledge was learned from other community members, especially from elders and local healers who share knowledge of the mode of collection, and the preparation and administration of medicinal plants.

Preparations of plants for medical use included decoction, paste, juice, chewing, and cooking or boiling (Table 5). The most common methods of the collection and preparation of medicinal plants are cutting the leaves, roots, stem or bark into small pieces and boiling them in water. For preparing a decoction, the plant parts are boiled until the liquid is reduced to about half or one third of the volume. Some decoctions are also used as steam baths. For pastes, plant parts are finely crushed or chewed, and then the resulting paste is applied to the affected part. For a juice, the plant part (mostly leaves and fruits) is extracted and drunk. For some remedies plant parts are chewed raw, then swallowed. Some plant materials can also be dried and stored for later use.

\section{Administration of medicines}

Medical administrations include oral intake, application to external body parts, rubbing/massage, and inhalation (Table 6). Most of the species were administered orally, mainly as a decoction or extracted from plant parts. A high number of species were

Table 5. Preparation of medicinal plants.

\begin{tabular}{lc}
\hline Preparation & Medical remedies (\%) \\
\hline Decoction & 50 \\
Paste & 24 \\
Juice & 14 \\
Chewing & 6 \\
Cooking/boiling & 4 \\
Powder & 2 \\
\hline
\end{tabular}

Table 6. Mode of administration of medical remedies.

\begin{tabular}{lc}
\hline Mode & No. of remedies \\
\hline Oral intake & 199 \\
External application & 71 \\
Rubbing/massage & 14 \\
Inhalation & 3 \\
\hline
\end{tabular}


externally applied mostly to treat wounds, snakebites, bleeding and itches. Rubbing applied to treat back pain, muscle pain, and in only three remedies local people applied inhalation, for instance of steam from Eucalyptus camaldulensis and bamboo leaves in boiling water, to treat fever or cold.

\section{Commercialization of medicinal plants}

A total of 18 medicinal plant species in Ben En National Park are commercialized (Appendix 2); of these Zingiber officinale (Zingiberaceae) and Allium sativum (Alliaceae) are cultivated species. Curcuma zedoaria (Zingiberaceae) is both cultivated and wild. Three wild species in high market demand are Morinda officinalis (Rubiaceae), Amomum villosum (Zingiberaceae) and Spatholobus suberectus (Fabaceae).

Most of the species are sold to traders or in the market of the Nhu Thanh and the Nhu Xuan districts. Traders usually sell roots of Morinda officinalis, roots of Polygonum multiflorum, roots and stems of Smilax glabra, roots of Gynura japonica and stems and barks of Abrus precatorius to traditional medicine shops in big cities in Vietnam. Spatholobus suberectus and Amomum villosum are exported to China.

The demand of the market and the collection intensity of Morinda officinalis used as aphrodisiac are especially high. From our botanical field surveys (Hoang et al. in prep.) it appeared that this species has become endangered by overcollecting of the entire plant, and will soon be extinct, at least locally, if no attempts are made to get the plant into cultivation.

\section{Importance of medicinal plant species for the local people in Ben En National Park}

Importance for health care

The eight most important species for health care by local communities are listed in Table 7. Most of them are used to treat common diseases such as fever, colds, flu, weakness, and for treating women after childbirth.

Five species of these important medicinal plant species are already grown in home gardens, but the number of households planting them is still low (Table 7).

Table 7. The most important medicinal plants for people in Ben En National Park.

\begin{tabular}{|c|c|c|c|}
\hline \multirow{2}{*}{$\begin{array}{l}\text { Latin name } \\
\text { Asteraceae }\end{array}$} & \multirow{2}{*}{$\begin{array}{l}\text { Common name } \\
\text { Họ Cúc }\end{array}$} & \multirow[t]{2}{*}{$\begin{array}{l}\text { Perce } \\
\text { eholds cu } \\
\text { the }\end{array}$} & $\begin{array}{l}\text { ercentage of } \\
\text { s cultivating } \\
\text { the species }\end{array}$ \\
\hline & & & \\
\hline Artemisia vulgaris L. & Ngải cứu & Temperate Europe and Asia, wild, cultivated & 21 \\
\hline Fabaceae & Họ Đậu & & \\
\hline Spatholobus suberectus Dunn & Huyết rông Lào & Native, wild & 0 \\
\hline Abrus precatorius $\mathrm{L}$. & Cam thảo & India, wild & 0 \\
\hline Lamiaceae & Họ Hoa môi & & \\
\hline Leonurus sibiricus L. & Ích mẫu & Siberia, China, wild, cultivated & 12 \\
\hline Ocimum tenuiflorum $\mathrm{L}$. & Hương nhu tia & Old World Tropics, wild, cultivated & 15 \\
\hline Plantaginaceae & Ho Mã đè & & \\
\hline Plantago asiatica $\mathrm{L}$. & Mã đè & Asia, wild, cultivated & 11 \\
\hline Zingiberaceae & Họ Gừng & & \\
\hline Zingiber officinale Blume & Gừng & China, Asia cultivated & 25 \\
\hline Amomum villosum Lour. & Sa nhân & China, wild & 0 \\
\hline
\end{tabular}


The use index of the medicinal plant species varies widely (Table 8, Appendix 1), from 0.01 to 1 , indicating that 2 species are only used by $1 \%$ of all households (Lonicera japonica (Caprifoliaceae) and Xylopia vielana (Annonaceae)), while 4 species are used by all households, all of them are common and cultivated species (Camellia sinensis (Theaceae), Allium fistulosum, Allium sativum (Alliaceae), and Zingiber officinale (Zingiberaceae)). The majority of species are used by less than half of the households, and $68 \%$ of the species have use indices lower than 0.25 (Table 8). On average, households use 25 medicinal plant species for disease treatment (Table 8).

\section{Importance for income generation}

The monetary income value for local people was calculated for each listed species.

A total of 18 medicinal plant species are commercialized in Ben En National Park, but the most important species for local income are Amomum villosum (Zingiberaceae) and Spatholobus suberectus (Fabaceae). The average income from Amomum villosum is US\$ 11 per year per household; this is about $2.5 \%$ of the total income. Spatholobus suberectus yields about US\$ 18 per year per household (4.3\% of the total income). The other species do not generate much income, though Morinda officinalis (Rubiaceae) has a high price but it is very rare in the field and the amount collected by local people is small. Income of local people per household in Ben En National Park is shown in Table 9.

Table 9. Income of local people per household in Ben En National Park.

\begin{tabular}{lccl}
\hline Resource & Income in US\$ & Percentage $(\%)$ & Remarks \\
\hline Agriculture & 150 & 36 & Crops such as rice and corn \\
Livestock & 100 & 24 & Pigs, chickens, dogs, and cows \\
Non medicinal & 50 & 12 & Bamboo, rattan, resin, timber, \\
useful plants & & & firewood, etc. \\
Medicinal plants & 45 & 11 & See Appendix 2 \\
Others & 75 & 17 & Employment, fishing, trading, etc. \\
Total & 420 & 100 & \\
\hline
\end{tabular}

\section{Comparison with other regional studies on medicinal plants in Vietnam and in the region}

To see whether medicinal plants in Ben En National Park had characteristics in common with those of other national parks in Vietnam, the results of this study were compared with the medicinal plant uses recorded by other authors. Both wild and cultivated medicinal species were taken into account (Table 10).

The result of this study was also compared with the medicinal plant uses recorded in the PRoseA Handbooks on Medicinal and poisonous plants (De Padua et al. 1999, Van Valkenburg \& Bunyapraphatsara 2001, Lemmens \& Bunyapraphatsara 2003) and Van Reede tot Drakestein's Hortus Malabaricus (1668-1692, Manilal 2003). Out of the total 
Table 10. Comparison of medicinal plants in Ben En National Park with other regions in Vietnam.

\begin{tabular}{|c|c|c|c|c|c|}
\hline Study & National Park & Ethnic groups & $\begin{array}{r}\text { Size of } \\
\text { population }\end{array}$ & Area $\left(\mathrm{km}^{2}\right)$ & $\begin{array}{r}\text { No. of } \\
\text { medicinal } \\
\text { plant species }\end{array}$ \\
\hline This study & Ben En & $\begin{array}{l}\text { Kinh, Muong, Thai, } \\
\text { Tay, Tho }\end{array}$ & 18,000 & 15,800 & 230 \\
\hline $\begin{array}{l}\text { Tran \& Ziegler } \\
2001\end{array}$ & Banh Ma & $\begin{array}{l}\text { Kinh, Ta ku, Van kieu, } \\
\text { H Mong }\end{array}$ & 65,000 & 22,031 & 432 \\
\hline On 2003 & $\mathrm{Ba} \mathrm{Vi}$ & Dao & 46,547 & 6,768 & 503 \\
\hline $\begin{array}{l}\text { Thin \& Nhan } \\
2003\end{array}$ & Pu Mat & $\begin{array}{l}\text { Kinh, Thai, Kho Mu, } \\
\text { Dan Lai, Poong, } \\
\text { H Mong, O Du, Tay }\end{array}$ & 93,333 & 91,113 & 610 \\
\hline Chi 1996 & Entire Vietnam & 54 ethnic groups & $85,000,000$ & $330,000,000$ & 3200 \\
\hline
\end{tabular}

of 230 medicinal plant species in Ben En National Park 128 species are listed in the PRosEA Handbooks on Medicinal and poisonous plants and 41 species used by local people in Ben En National Park were also used in the 17th century in Southwest India according to Van Reede's Hortus Malabaricus (Manilal 2003). Differences and similarities in the medicinal use of these species will be considered in the discussion.

\section{Public perception and awareness}

In the research area many people are able to identify medicinal plants and give recipes, but the young members of the communities demonstrate little interest in learning the traditional ethnomedical lore. About $43 \%$ of young people in all households interviewed do not know about medicinal plants and $25 \%$ do not want to learn how to use traditional medicinal plants for disease treatment. Moreover, many local people tend to use synthetic medicine instead of medicinal plants. About $47 \%$ of the households interviewed prefer to use western medicine if they can afford it.

Most local people in Ben En National Park recognized that medicinal plants are important for the health care of communities, especially for poor people. They also agreed that medicinal plants in Ben En National Park would not be endangered if they

Table 11. Medicinal plants in Ben En National Park listed in the Red data book of Vietnam (Ban 2007) and the Red list of threatened species of IUCN (2006). $\mathrm{E}=$ Endangered; LR $=$ Least concern; $\mathrm{nl}=$ not listed; $\mathrm{T}=$ Threatened; $\mathrm{V}=$ Vulnerable.

\begin{tabular}{|c|c|c|c|}
\hline Species & Family & $\begin{array}{l}\text { Threat category } \\
\text { in Red data book } \\
\text { Vietnam }\end{array}$ & $\begin{array}{l}\text { Threat category } \\
\text { in Red list of IUCN } \\
2006\end{array}$ \\
\hline Alstonia scholaris L. & Apocynaceae & $\mathrm{nl}$ & LR \\
\hline Anoectochilus roxburghii (Wall.) Lindl. & Orchidaceae & $\mathrm{E}$ & $\mathrm{nl}$ \\
\hline Ardisia silvestris Pit. & Myrsinaceae & $\mathrm{V}$ & $\mathrm{nl}$ \\
\hline Caesalpinia sappan $\mathrm{L}$. & Caesalpiniaceae & $\mathrm{nl}$ & LR \\
\hline Cycas pectinata Buch.-Ham. & Cycadaceae & $\mathrm{V}$ & V \\
\hline Drynaria fortunei (Mett.) J.Sm. & Polypodiaceae & $\mathrm{T}$ & $\mathrm{nl}$ \\
\hline Polygonum multiflorum Thunb. & Polygonaceae & $\mathrm{V}$ & $\mathrm{nl}$ \\
\hline Rauvolfia verticillata (Lour.) Baill. & Apocynaceae & $\mathrm{V}$ & $\mathrm{nl}$ \\
\hline
\end{tabular}


Table 12. Medicinal plants considered as threatened species in Ben En National Park. E = Endangered; $\mathrm{R}=$ Rare; $\mathrm{T}=$ Threatened.

\begin{tabular}{llc}
\hline Species & Family & Threat category \\
\hline Acorus gramineus Sol. & Araceae & $\mathrm{R}$ \\
Anoectochilus roxburghii (Wall.) Lindl. & Orchidaceae & $\mathrm{E}$ \\
Ardisia silvestris Pit. & Myrsinaceae & $\mathrm{E}$ \\
Caesalpinia sappan L. & Caesalpiniaceae & $\mathrm{R}$ \\
Catharanthus roseus L. & Apocynaceae & $\mathrm{T}$ \\
Cibotium barometz (L.) J.Sm. & Dicksoniaceae & $\mathrm{T}$ \\
Cissampelos pareira L. & Menispermaceae & $\mathrm{R}$ \\
Coscinium fenestratum (Gaertn.) Colebr. & Menispermaceae & $\mathrm{E}$ \\
Cycas pectinata Buch.-Ham. & Cycadaceae & $\mathrm{T}$ \\
Drynaria fortunei (Mett.) J.Sm. & Polypodiaceae & $\mathrm{R}$ \\
Fibraurea recisa Pierre & Menispermaceae & $\mathrm{T}$ \\
Morinda citrifolia L. & Rubiaceae & $\mathrm{R}$ \\
Morinda officinalis Haw. & Rubiaceae & $\mathrm{E}$ \\
Polygonum multiflorum Thunb. & Polygonaceae & $\mathrm{V}$ \\
Rauvolfia verticillata (Lour.) Baill. & Apocynaceae & $\mathrm{T}$ \\
Smilax glabra Wall. & Smilacaceae & $\mathrm{T}$ \\
Stephania longa Lour. & Menispermaceae & $\mathrm{R}$ \\
Stephania rotunda Lour. & Menispermaceae & $\mathrm{R}$ \\
\hline
\end{tabular}

are only harvested for local treatment of diseases and not for commercial purposes. About $82 \%$ are aware that such practices had caused a decline in the abundance of many species during the last few years, especially of the expensive, economically exploited species.

\section{Conservation status}

Three medicinal plant species from Ben En are listed in the Red data list of IUCN (2006). However, there are 6 medicinal plant species used by local communities in Ben En National Park that are listed in the Red Data Book of Vietnam Vol. 2. (Ban 2007) (Table 11). At the local level, 18 medicinal plant species appear to be endangered, rare, or threatened (Table 12).

\section{DISCUSSION}

\section{The commercial potential of medicinal plants in Ben En National Park}

The diversity of medicinal plants in Ben En National Park could have a much larger potential for the local people in the research area in particular and for Vietnam in general if the medicinal plants would be processed in a more sophisticated manner, e.g. in ready-to-use tonics and powders. On the other hand, the number of commercialized medicinal plant species in Ben En National Park (18 species) is lower than in other regions: for instance, 54 species in Ba Vi National Park (On 2003) are commercialized. Moreover, the prices of commercial medicinal plant species in Ben En are not stable. The two most important species to generate income are Amomum villosum and especially Spatholobus suberectus. The revenues they generate still depend on the traders. It would be better if local communities organized the market system. Furthermore, local people should understand and establish sustainable harvesting methods, especially for 
the species of high value and importance for income generation. Last but not least, the commercially valuable medicinal plant species should be further studied and planted in home gardens.

\section{Loss of traditional knowledge}

Traditional medicinal plant species are not only important for health care of local communities but also of some importance to generate income. However, the present knowledge on traditional healing practices is being lost rapidly. Only few of the local people younger than 25 year participate in collecting medicinal plants compared to those older than 50 (Table 4). Furthermore, many young members of the communities do not know about medicinal plants and show little interest in learning the traditional ethnomedical lore. Traditional knowledge of medicinal plants can get easily lost because many local people tend to use synthetic medicine instead of medicinal plants. To protect and develop the valuable knowledge of traditional medicinal plants their use should be encouraged, especially among the younger generation.

\section{Comparisons with other regional studies on medicinal plants in Vietnam and in the region}

The general patterns of plant use recorded in Ben En National Park show overlap with other ethnomedicinal studies from other national parks. Many of the recipes and ideas about illnesses and healing in Ben En are similar to those in $\mathrm{Ba} \mathrm{Vi}$ (On 2003) and $\mathrm{Pu}$ Mat (Thin \& Nhan 2003). But the comparisons also show that the number of medicinal plant species used by local people in Ben En is smaller than in other national parks in Vietnam (Table 10). The reason may be that the population living in the core and buffer zone of Ben En is much smaller than in other parks. Moreover, this is the first study on medicinal plants in Ben En National Park, while the number of medicinal plants used by local people according to earlier research in other regions also was smaller than according to more recent results, e.g. 200 species found in Ba Vi National Park (On 2000) (now 503 species); 200 species found in Pu Mat National Park (On 2003) (now 610 species). So future research may show the number of medicinal plant species in Ben En to be higher than the 230 species recorded so far.

A total of 172 medicinal plant species in Ben En National Park (about 75\%) are also used medicinally by local people in Pu Mat National Park (Thin \& Nhan 2003). Out of these 172 species, 138 species show at least one disease treatment overlapping in use and application in the two parks. The ethnic minority groups in the two regions are quite similar; both regions have Kinh, Thai, and Tay groups, and this could account for similar traditional uses. In the remaining 34 species there are no similarities in the medicinal uses, for example Glochidion velutinum (Euphorbiaceae) is used in Pu Mat to treat oedema; in Ben En it is used to treat stomach ache and toothache.

The Dao ethnic group in Ba Vi National Park (On 2003) uses 114 of the medicinal plant species (about 49\%) recorded here as traditional medicinal plants in Ben En National Park. Out of these 114 medicinal species, 48 overlap in at least one disease treatment between the two parks. In the remaining 68 species there are no similarities in the medicinal uses. For example, Rauvolfia verticillata (Apocynaceae) is used in 
$\mathrm{Ba} \mathrm{Vi}$ against diarrhoea; in Ben En it is used to treat sores and itches. Gymnema inodorum (Asclepiadaceae) in $\mathrm{Ba} \mathrm{Vi}$ is used to treat rheumatism; in Ben En it is used to cure indigestion. This huge divergence in traditional use of medicinal plant species in two regions is hard to understand. It raises questions about the efficacy of traditional healing methods on the one hand and on the role of cultural divergence in health care, on the other.

In order to place these patterns in a broader perspective our results on the medicinal uses of plants in the Ben En National Park were also compared with two other detailed sources of information on traditional use of medicinal plants in Asia: Hortus Malabaricus and the three PROSEA handbook volumes on Medicinal and Poisonous Plants from South-East Asia.

The Hortus Malabaricus by Van Reede tot Drakenstein, consulted in the English translation (Manilal 2003), contains a detailed account of 690 species from the Malabar Coast in India (the modern state of Kerala) with information on their medicinal uses contributed and verified by local traditional healers and Brahmins (Heniger 1986). Although the floras of SW India and Vietnam are far apart and very different, 41 species out of the 230 medicinal species from Ben En National Park were also used medicinally in India in the 17th century and documented in the Hortus Malabaricus (the asterisked species in Appendix 1). A very precise comparison of the uses and (presumed) activity of the medicinal preparations is not possible because both Hortus Malabaricus and our own survey suffer from the fact that actual diseases are not properly identified in line with modern medical knowledge, but rather very general symptoms are listed that may be caused by many different diseases (such as stomach ache, headache, fever, swellings, weakness, etc., cf. Appendix 1). Nevertheless, it is most striking that the same species were in most cases apparently used to treat entirely different symptoms by the 17 th century inhabitants and doctors of Kerala when compared with the 21 st century local healers in Ben En National Park. For instance, out of the 41 species only 9 show some overlap in their use and application between the two regions, usually concerning only general symptoms like headaches, fever or itches. In the remaining 32 species no similarities in the medicinal uses could be detected at all. To give just two examples: Morinda citrifolia (Rubiaceae) was used in India to treat gout; in Ben En National Park it is used as an aphrodisiac and to treat sores; Phyllanthus reticulatus was used in India as a mouth wash and to treat rheumatism and stomach ailments; in Ben En it is used to cure skin burns. This huge divergence in traditional use of these 41 species raises similar questions about the efficacy and reliability of traditional healing methods in general as signalled above. One might also question the reliability of the informants in both analyses.

A total of 128 medicinal species from Ben En (56\% of the species) have also been reviewed in the Prosea Handbooks on Medicinal and Poisonous Plants from South-East Asia (De Padua et al. 1999, Van Valkenburg \& Bunyapraphatsara 2001, Lemmens \& Bunyapraphatsara 2003). In the PROSEA Handbooks information on traditional and modern use of medicinal plants is comprehensively abstracted for the whole region from continental South-East Asia (including Vietnam and Thailand) to the Indo-Pacific (Malaysia, Indonesia, the Philippines, Papua New Guinea). Here the overlap with applications documented is much greater. This is not surprising because 
widespread medicinal species appear to have a very wide range of traditional uses, often highly divergent from country to country or region to region, which increases the probability that a single traditional use communicated by the local people from Ben En is among the manifold uses documented for the whole of South-East Asia. PROSEA information thus also shows a fairly high overlap with ancient uses documented in Hortus Malabaricus. In over two thirds of the medicinal species from Ben En the local application agrees with one of the numerous applications recorded in the PROSEA Handbooks. Nevertheless, for 35 species the medicinal use reported by village elders, households and local doctors in Ben En appears to be 'new'. For instance Achyranthes aspera (Amaranthaceae) used to treat nervous debility in Ben En, is elsewhere used to treat wounds, abscesses and boils, rheumatism, stomach ache, menstruation pains, etc; Tetracera scandens (Dilleniaceae) used to treat rheumatism in Ben En, has a very wide range of applications throughout South-East Asia, including the treatment of snakebites, coughs, burns and diarrhoea without any record for rheumatism (Van Valkenburg \& Bunyapraphatsara 2001). These and other divergences between our results from the field survey and interviews in Ben En and information documented in the literature suggest that both broad and narrow inventories of medicinal plants may still be very incomplete and that further critical study is needed.

\section{ACKNOWLEDGEMENTS}

The authors are grateful to the Vietnamese government for financially supporting Mr. Hoang Van Sam to carry out the project at Leiden University. We are also grateful to the International Foundation of Science (IFS) for financial support to do the field work in Ben En National Park. We would like to thank Prof. J. Slikkerveer for his useful comments. Dr. F.A.C.B. Adema, Dr. M.M.J. van Balgooy, the late Dr. Ding Hou, Dr. H.P. Nooteboom, Prof. P.C. van Welzen, and Dr. W.J.J.O. de Wilde (National Herbarium of the Netherlands, Leiden University branch), Mr. Nguyen Van Huy, Mr. Nguyen Van Nghia, Mr. Tran Ngoc Hai, Mr. Le Mong Chan (Vietnam Forestry University) kindly helped us to identify many species which is gratefully acknowledged. In addition we thank many staff and local people in Ben En National Park for their support, especially Mr. Nguyen Danh Hien, Mr. Luong Xuan Ha, Mr. Dang Huu Nghi, and Mr. Le Dinh Phuong. We also would like to thank Mr. Hoang Van Cuong, Mr. Vu Van Dinh, Mr. Pham Thanh Trang and Miss Nguyen Tuan Phuong, students at the Vietnam Forestry University for their assistance in the field.

We are very grateful to Dr. P.H. Hovenkamp and Dr. T. van Andel for critically reading earlier versions of the manuscript.

\section{REFERENCES}

Anonymous. 2000. The list of plants and animals in Ben En National Park. Report from Sub Institute of Forest Inventory and Planning II, Nghe An, Vietnam: 1-28.

Ban, N.T. (ed.). 2007. Red data book of Vietnam. Vol. 2. Science and Techniques Publishing House, Hanoi.

Chi, V.V. 1996. The dictionary of medicinal plants of Vietnam. Medical Publishing House, Hanoi.

De Lucena, R.F.P., E. de Lima Araujo \& U.P. de Albuquerque. 2007. Does the local availability of woody Caatinga plants (north-eastern Brazil) explain their use value? Economic Botany 61: 347-361.

De Padua, L.S., N. Bunyapraphatsara \& R.H.M.J. Lemmens (eds.). 1999. Plant Resources of SouthEast Asia No. 12 (1). Medicinal and poisonous plants 1. Backhuys Publishers, Leiden.

Farnsworth, N.R., O. Akerele, A.S. Bingel, D. Soejarto \& Z. Guo. 1985. Medicinal plants in therapy. Bulletin of the World Health Organization 63, 6: 965-981. 
Hamilton, A. 2003. Medicinal plants and conservation: issues and approaches. International Plants Conservation Unit, WWF-UK. Surrey, United Kingdom.

Heniger, J. 1986. Hendrik Adriaan van Reede tot Drakenstein (1636-1691) and Hortus Malabaricus. Balkema, Rotterdam-Boston.

Ho, P.H. 2000. An illustrated Flora of Vietnam. Youth Publisher. Ho Chi Minh.

Hoang, S. V., P. Baas. \& P.J.A. Keßler. 2008. Plant diversity in Vietnam and Ben En National Park. Agricultural Publishing House, Hanoi.

IUCN. 2006. The red list of threatened species. Available from http://www.redlist.org/info/tables/ table6a.

Kasparek, M., A. Gröger \& U. Schipmann. 1996. Directory for medicinal plants conservation. IUCN/ SSC Medicinal Plants Specialist Group. German Federal Agency for Nature Conservation, Bonn.

King, S.R., E.N. Meza, T.J.S. Carlson, J.A. Chinnock, K. Moran \& J.R. Borges. 1999. Issues in the commercialization of medicinal plants. Herbal Gram 47: 46-51.

Lemmens, R.H.M.J. \& N. Bunyapraphatsara (eds.). 2003. Plant Resources of South-East Asia No. 12 (1). Medicinal and poisonous plants 3. Backhuys Publishers, Leiden.

Loi, D.T. 1995. Medicinal trees and medicaments of Vietnam. 7th ed. Science and Technology Publishing House, Hanoi.

Manilal, K.S. 2003. English translation of Van Reede tot Drakenstein's Hortus Malabaricus Vol. 1-12. (Calicut), India.

Martin, G.J. 1995. Ethnobotany: A methods manual. Chapman \& Hall, London.

Mendelsohn, R. 1997. Valuing undiscovered pharmaceuticals in tropical forests. Notes on economic plants. Economic Botany 51, 3: 328.

Mendelsohn, R. \& M.J. Balick. 1995. The value of undiscovered pharmaceuticals in tropical forests. Economic Botany 49: 223-228.

Ngai, N.B. 2001. Methodology of rural appraisal. An introductory guide. Vietnam Forestry University, Hatay.

On, T.V. 2000. Medicinal plants in Ba Vi National Park. Hanoi Pharmacy University, Hanoi.

On, T.V. 2003. A survey of medicinal plants in Ba Vi National Park: Methology and implication for conservation and sustainable use. PhD thesis. Hanoi Pharmacy University, Hanoi.

Phillips, O. \& A.H. Gentry. 1993. The useful plants of Tambopata, Peru: Statistical hypotheses tests with a new quantitative technique. Economic Botany 47: 15-32.

PID \& NES. 1989. An introduction to participation, rural appraisal for rural resources management. Program for International Development, Clark University, Worcester Mass. and National Environment Secretariat, Ministry of Environment and Natural Resources, Nairobi.

Prance, G.T., W. Balee, B.M. Boom \& R.L. Carneiro. 1987. Quantitative ethnobotany and the case for conservation in Amazonia. Conservation Biology 1, 4: 296-310.

Slikkerveer, L. J. 1999. Ethnoscience, 'TEK' and its application to conservation. In: D.A. Posey (ed.), Cultural and spiritual values of biodiversity: 169-180. UNEP, Nairobi, Kenya.

Spjut, R.W. \& R.E. Perdue. 1976. Plant folklore: A tool for predicting sources of antitumor activity? Cancer Treatment Reports 60: 979-985.

Swerdlow, J.L. 2000. Nature's medicine: Plants that heal. National Geographic Society. Washington, DC.

Thin, N.N. \& T.N. Nhan. 2003. Flora of Pu Mat National Park. Publishing Agriculture House, Hanoi.

Tordoff, A., E. Fanning \& M. Grindley (eds.). 2000. Ben En National Park. Society for Environmental Exploration, London.

Tran, T.A. \& S. Ziegler. 2001. Utilization of medicinal plants in Bach Ma National Park, Vietnam. Medicinal Plant Conservation 7: 3-5.

Van Andel, T.R. 2000. Non-timber forest products in the north-west district of Guyana. TropenbosGuyana series 8. Wageningen.

Van Reede tot Drakenstein, H.A. 1688-1692. Hortus Malabaricus vol. I-XII. Amsterdam.

Van Valkenburg, J.L.C.H. \& N. Bunyapraphatsara. 2001. ProsEA. Volume 12, Medicinal and poisonous plants. Backhuys Publishers, Leiden. 


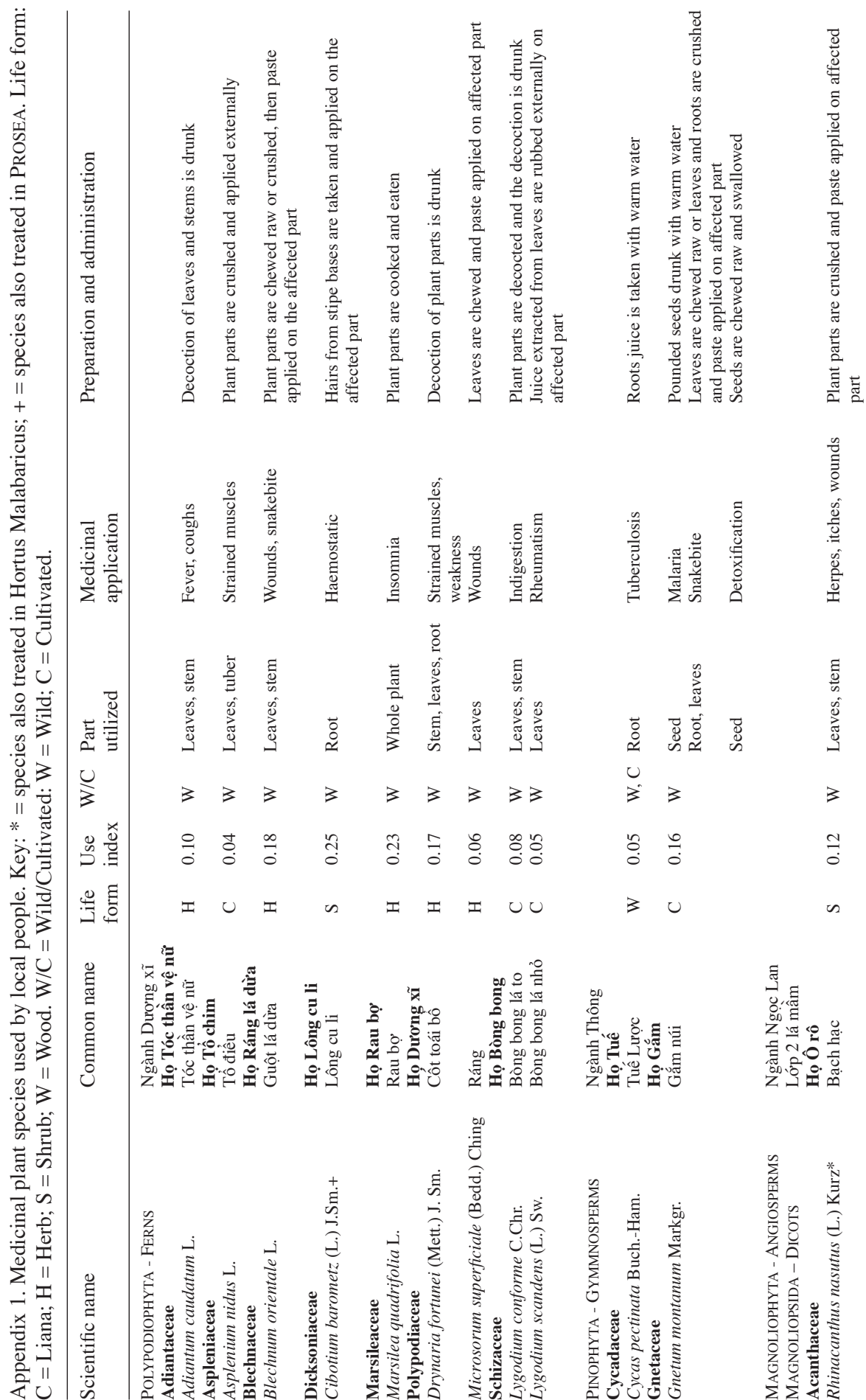




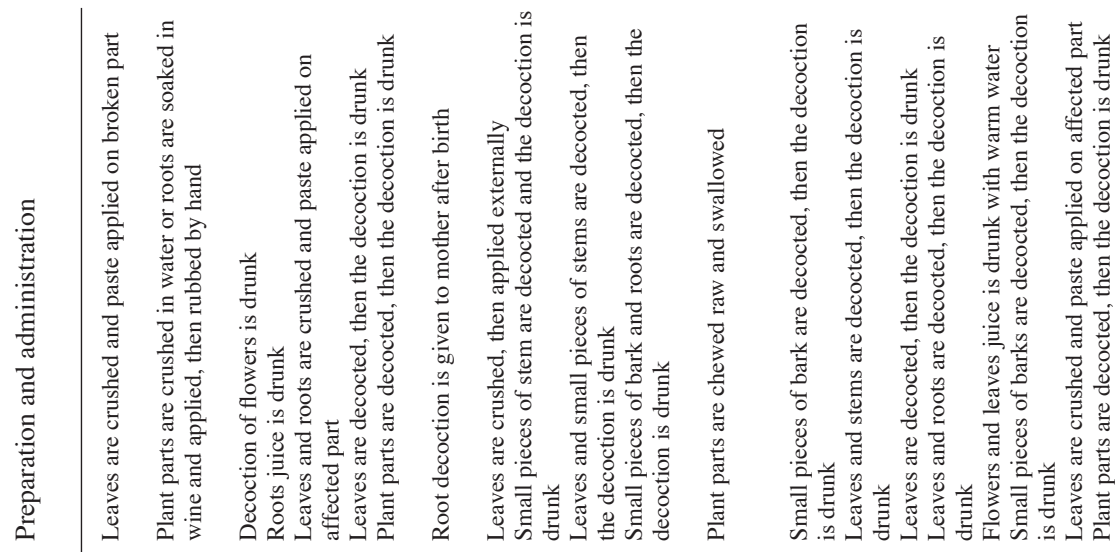

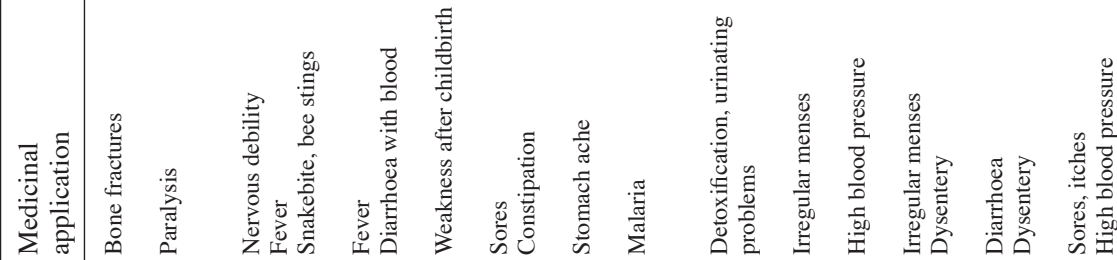

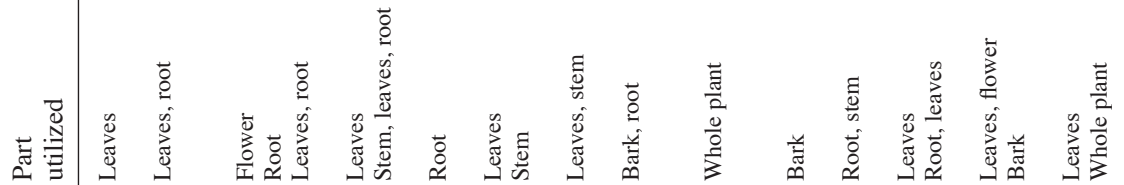

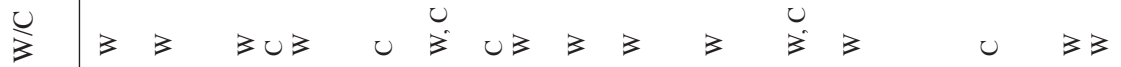

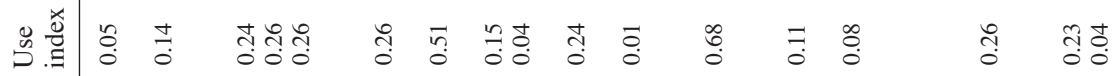

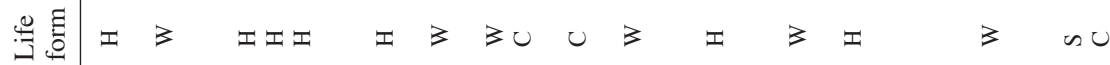

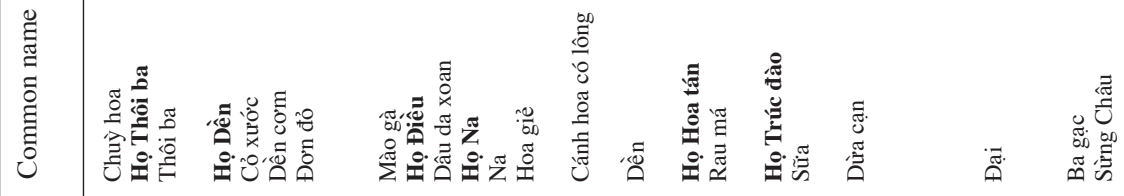

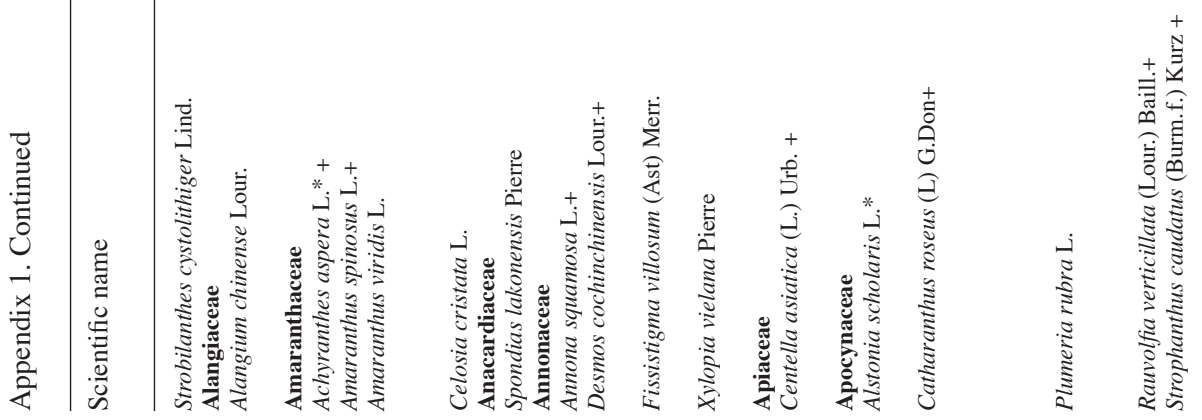



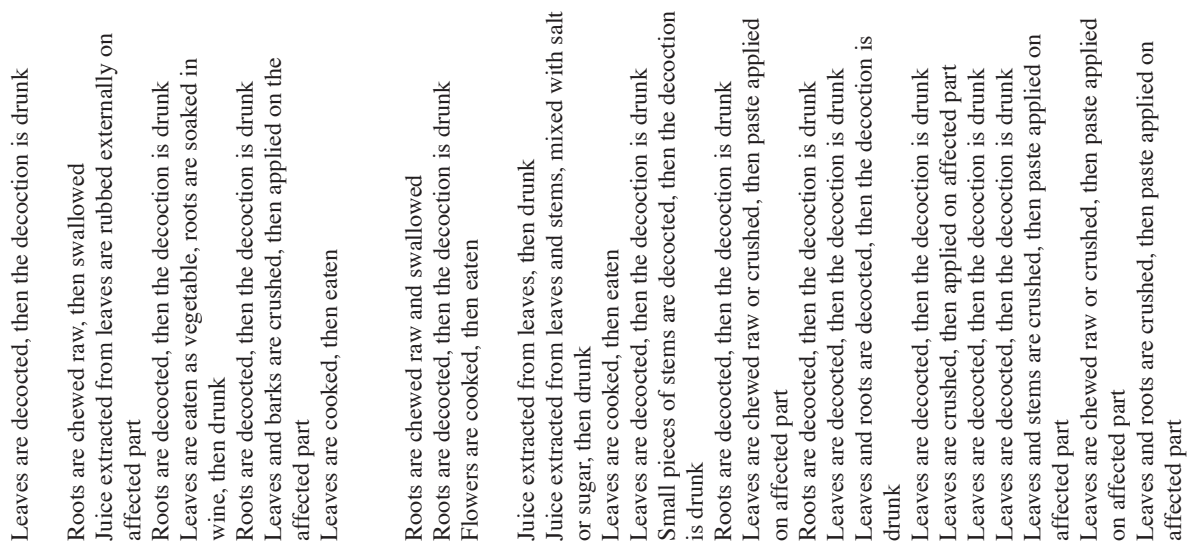

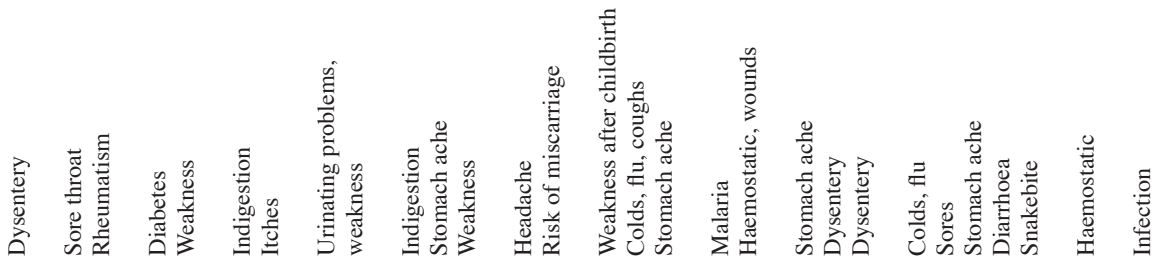

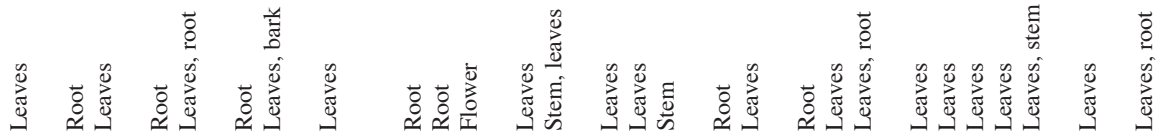

3330

๕. :

ㅇํㅇำ:

ָุ

กี่

$\geqslant 3$

n 30 I 3

$\cup \cup \cup \quad x$

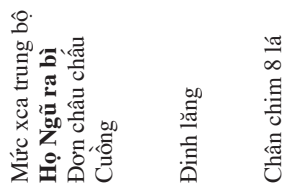

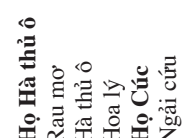

$\pm$

$\pm \pm$

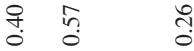

I I I
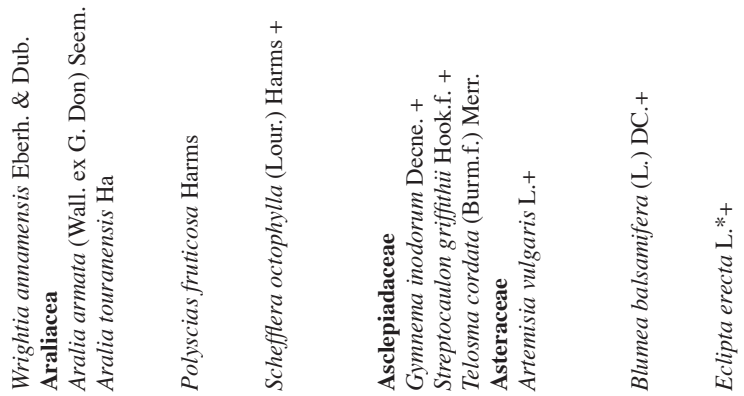

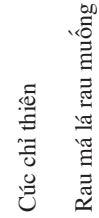

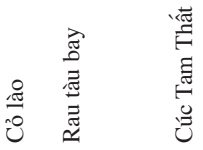

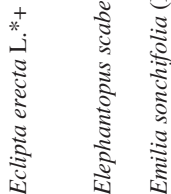

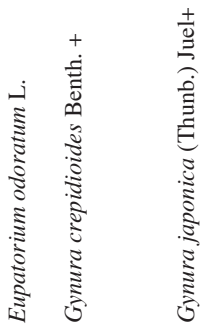




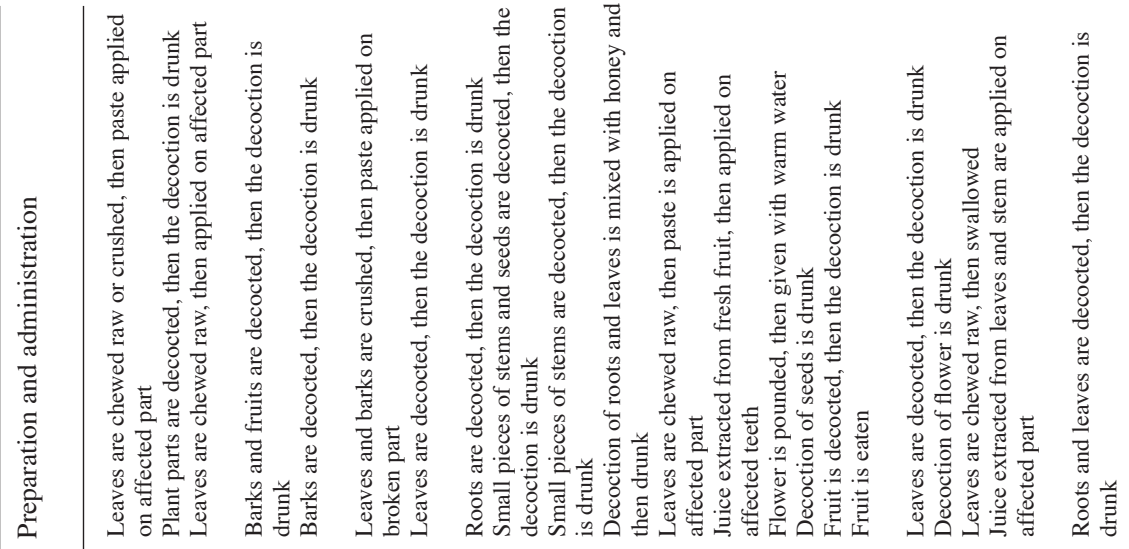

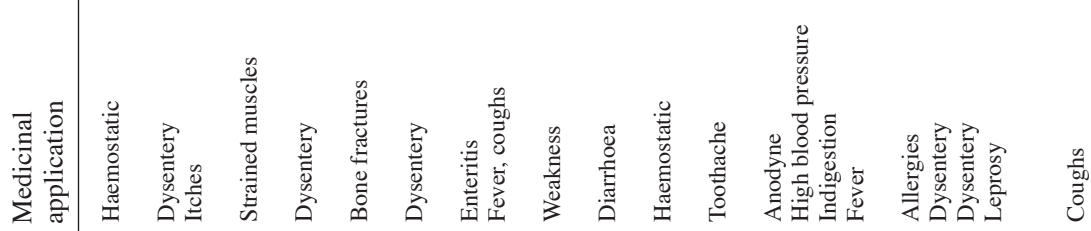

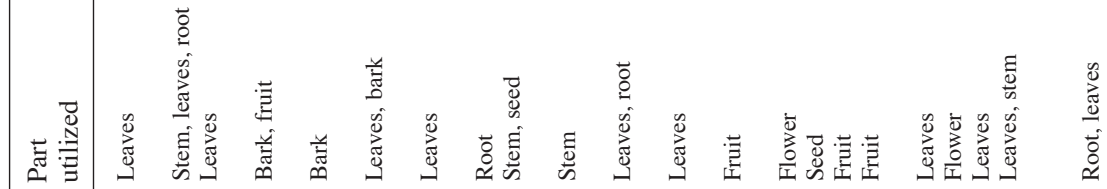

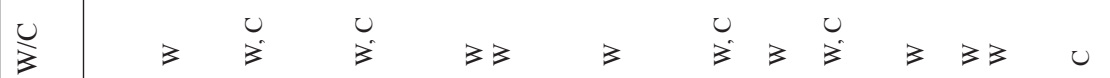

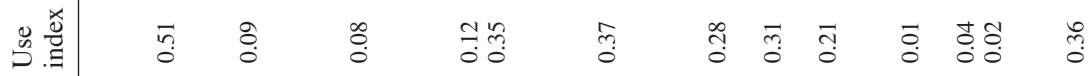

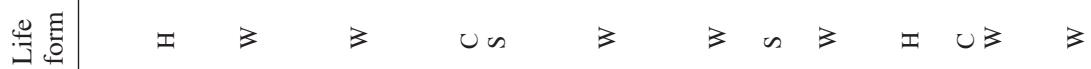

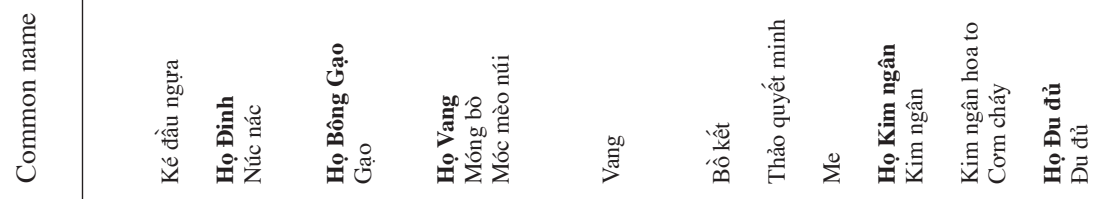

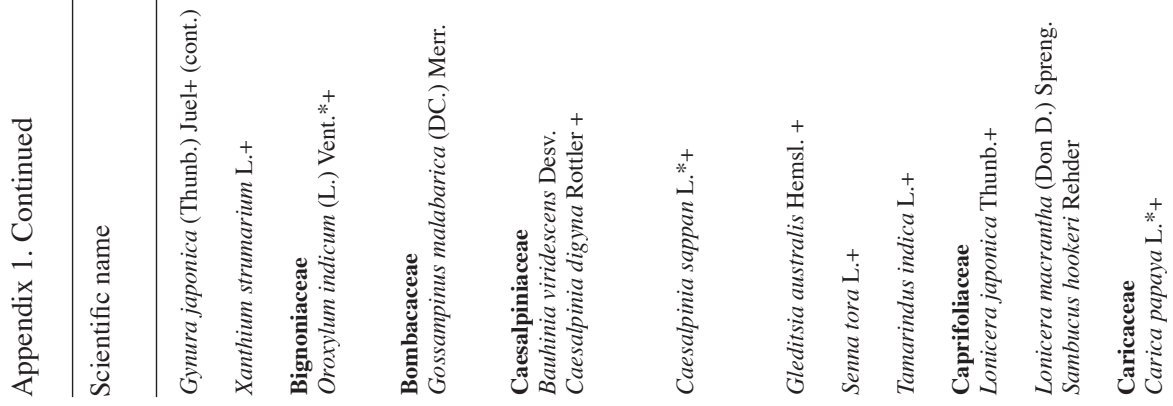




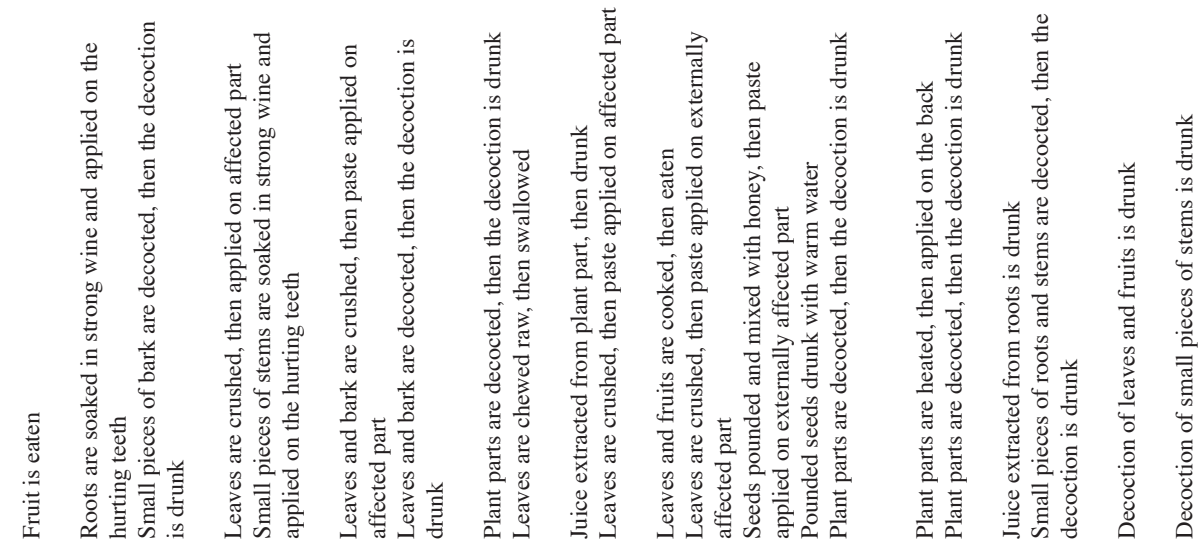

In

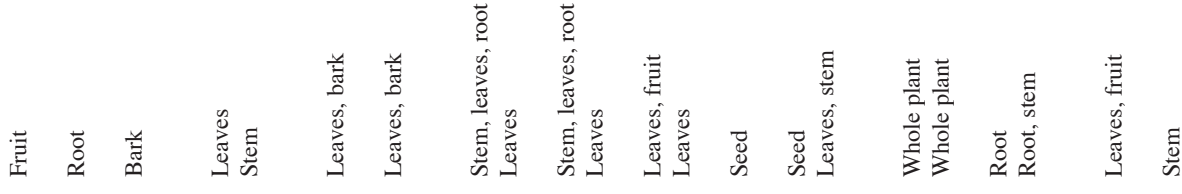

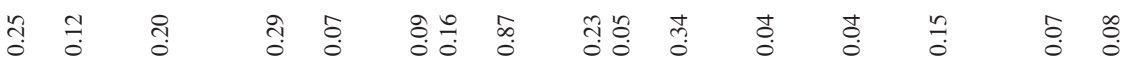

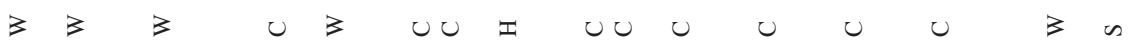

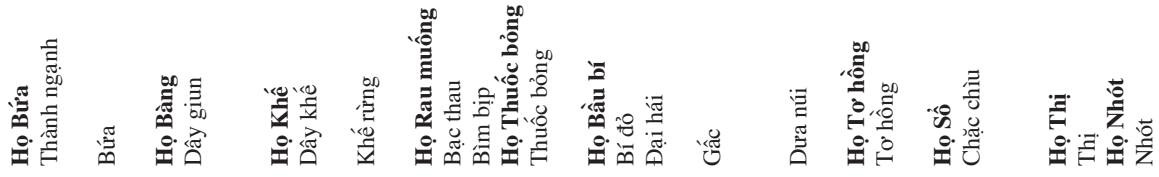

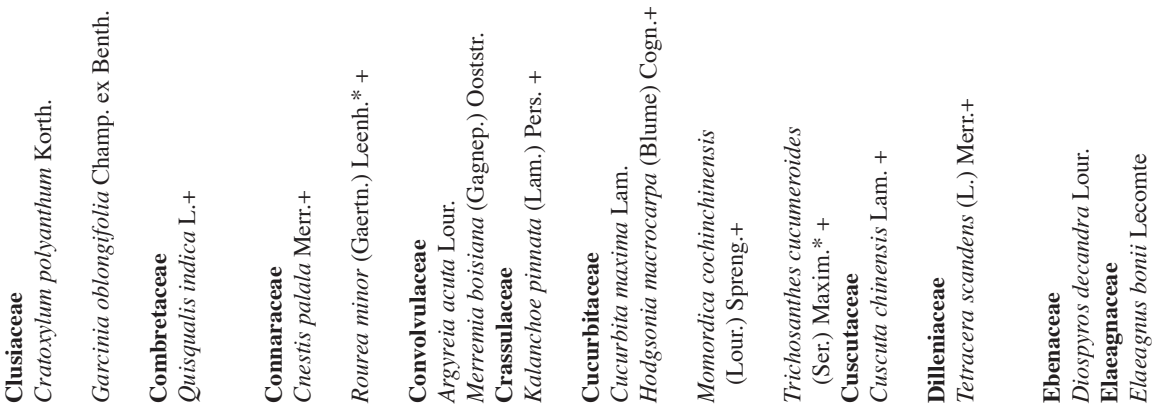




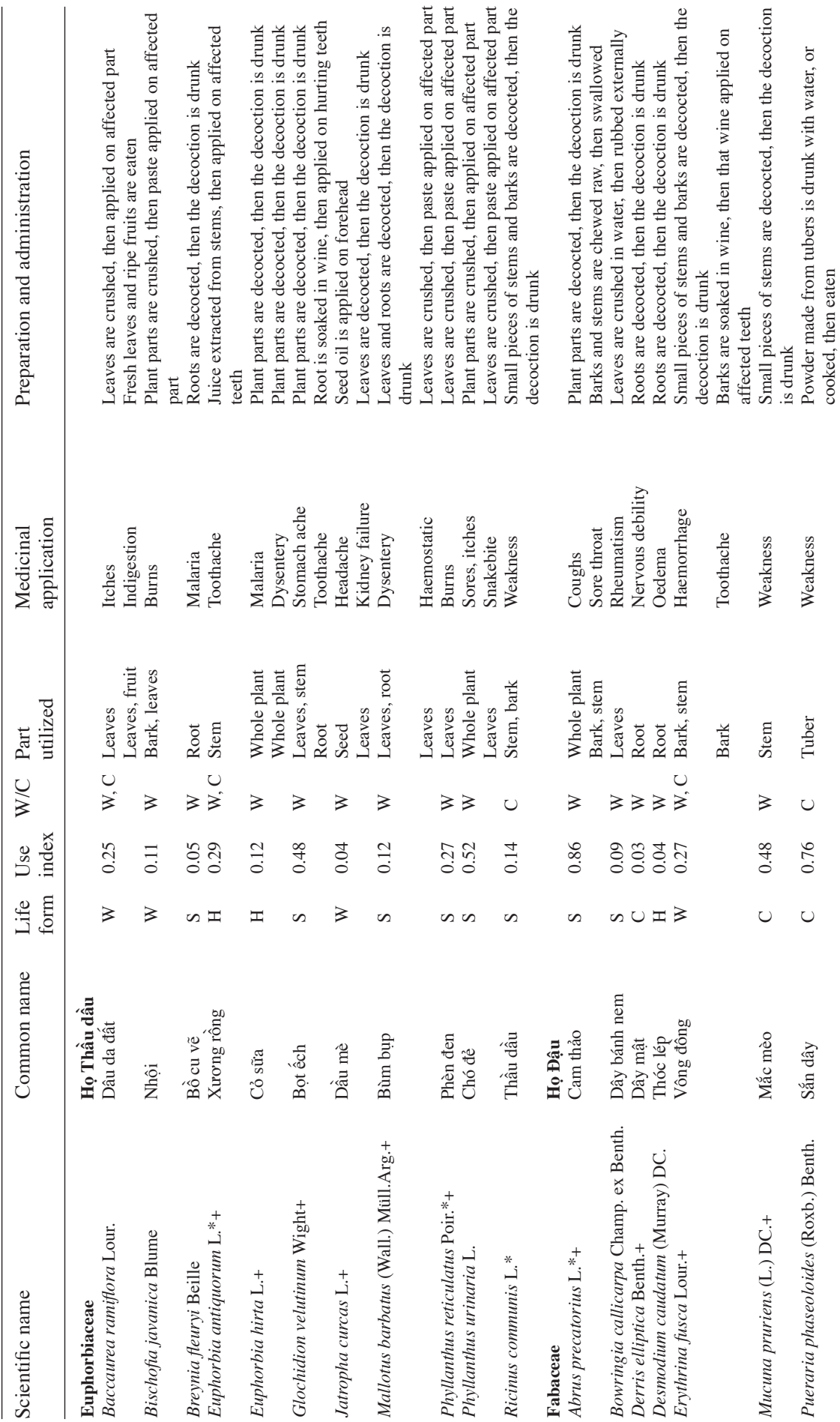




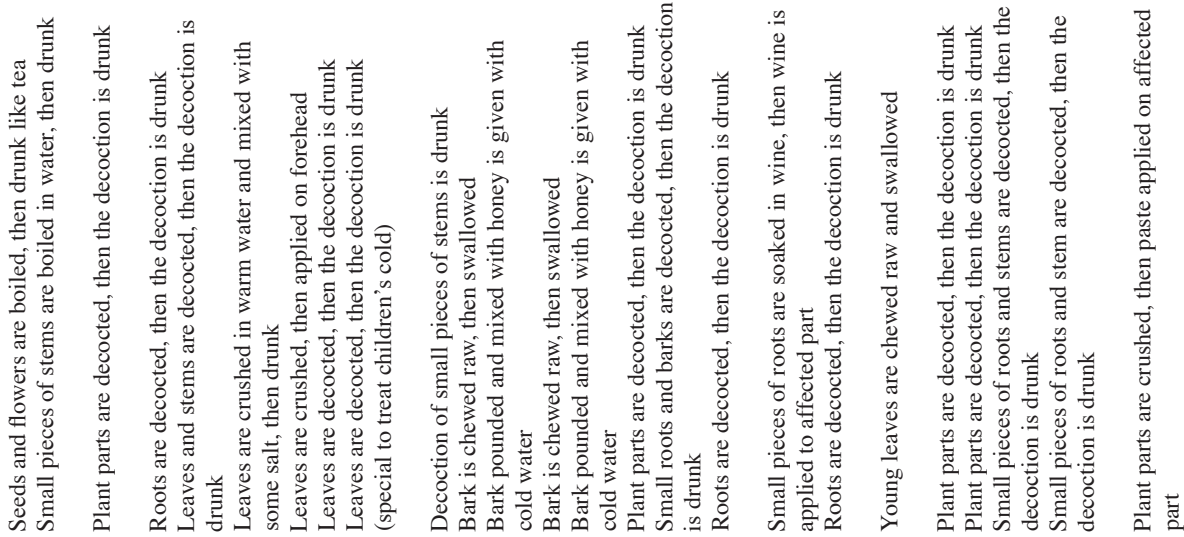

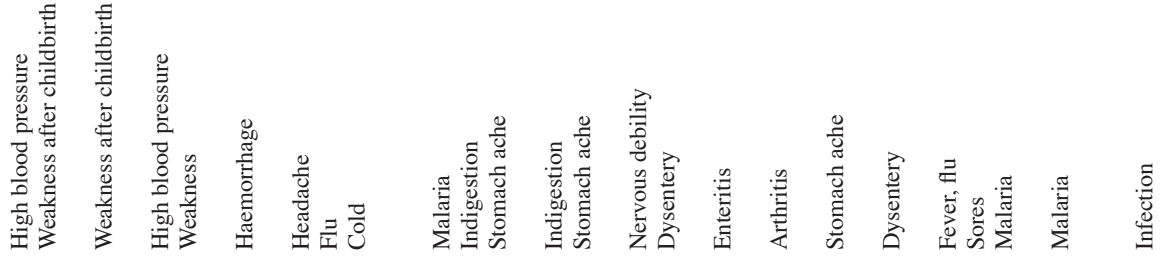

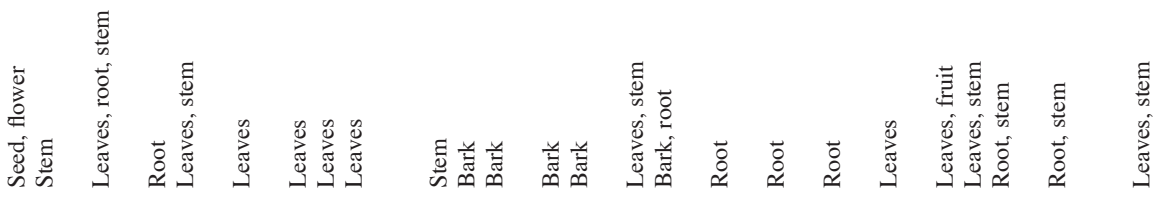

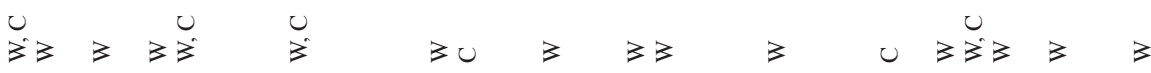

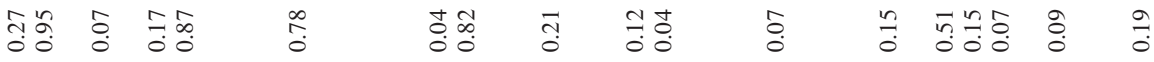

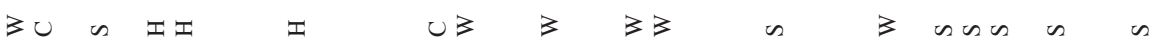

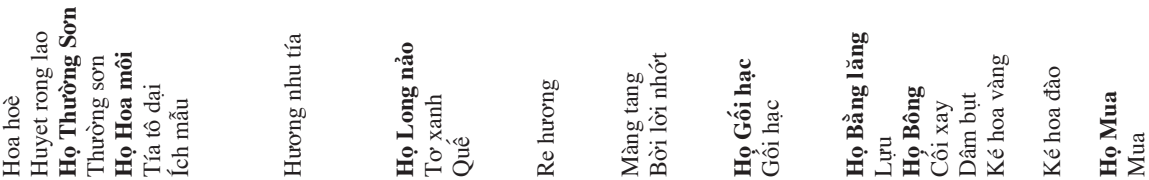

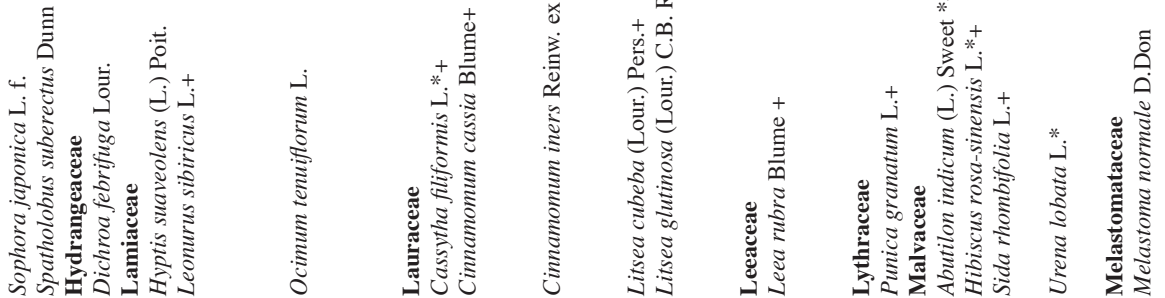




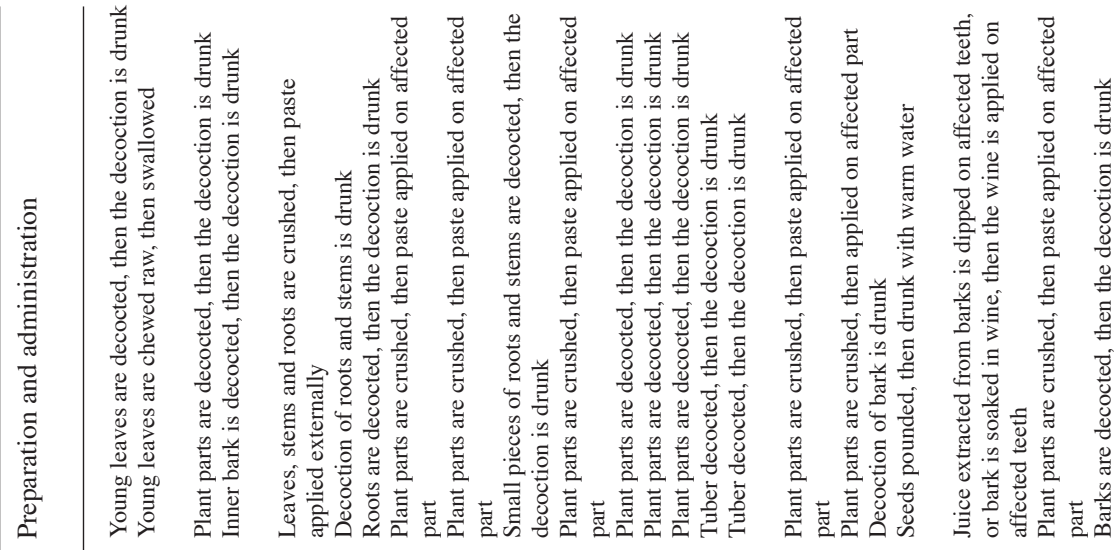

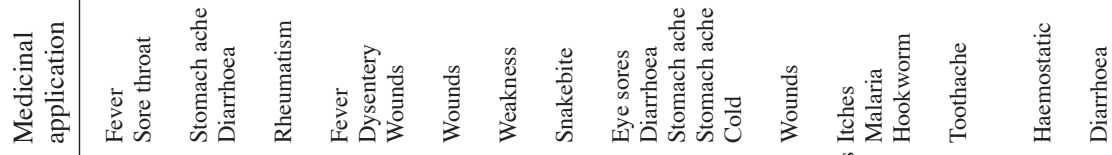

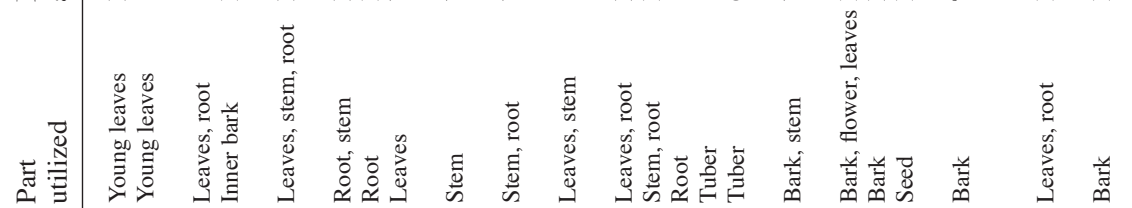

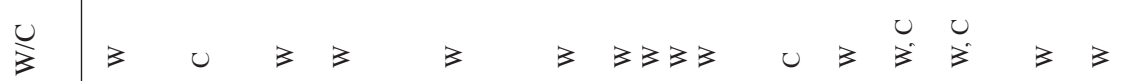

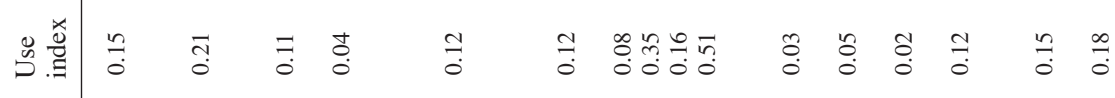

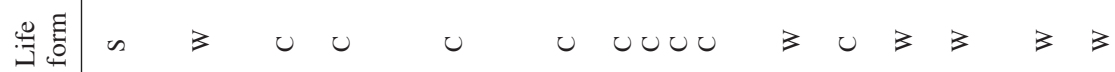

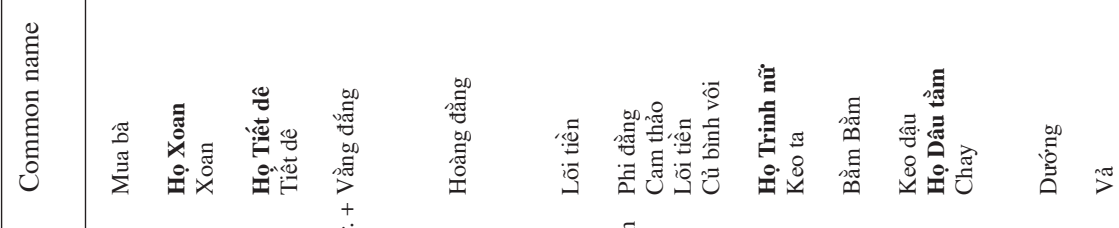

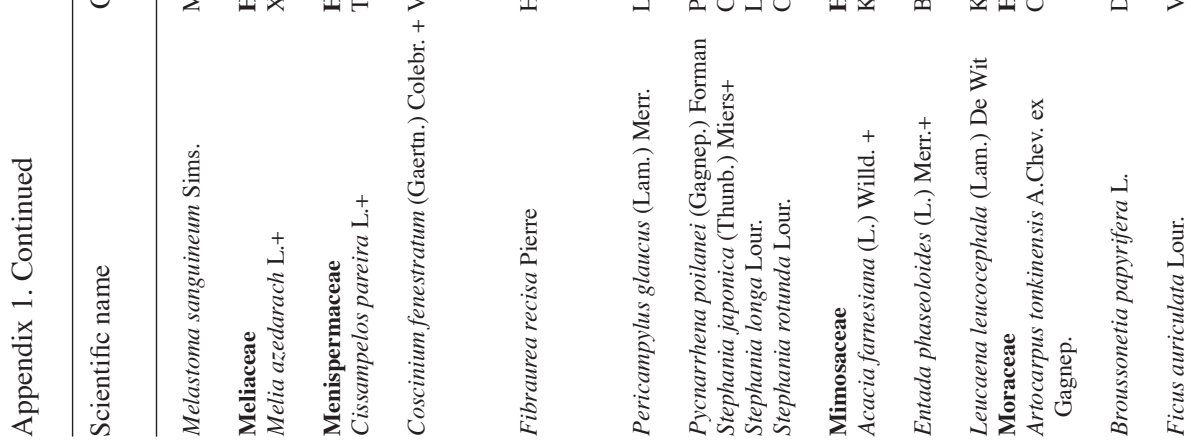




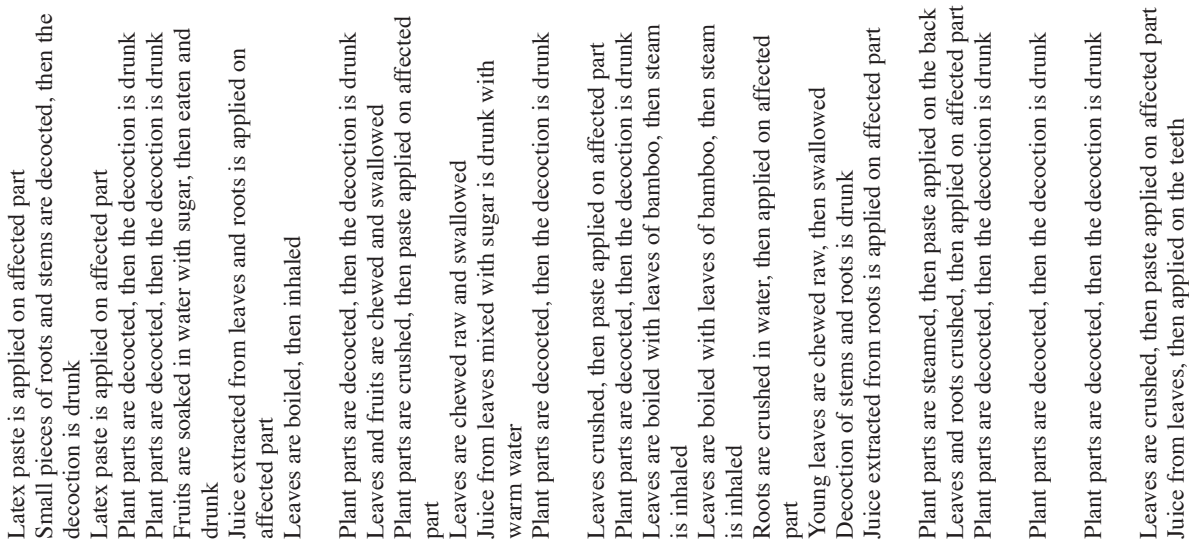

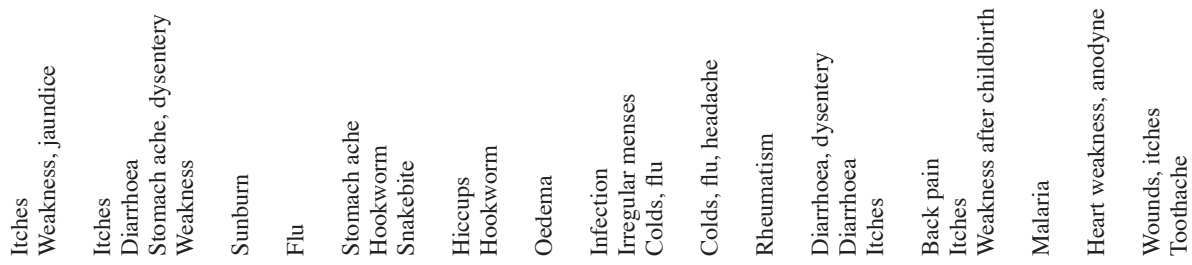

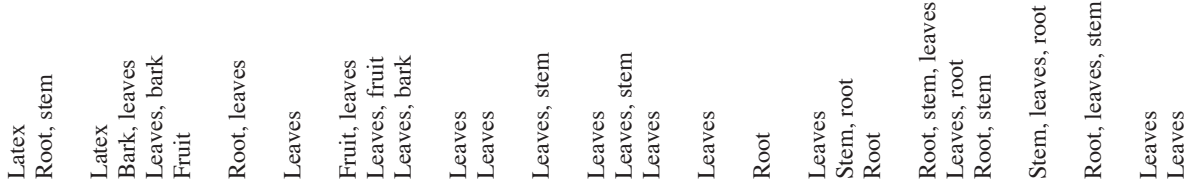

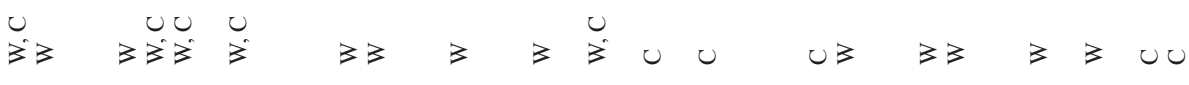

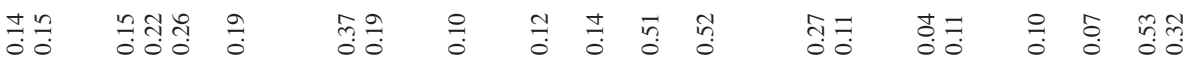

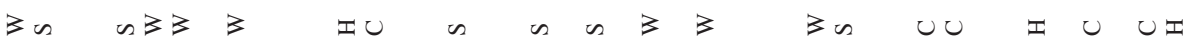

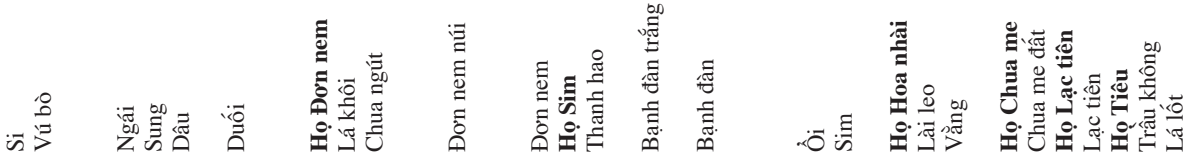

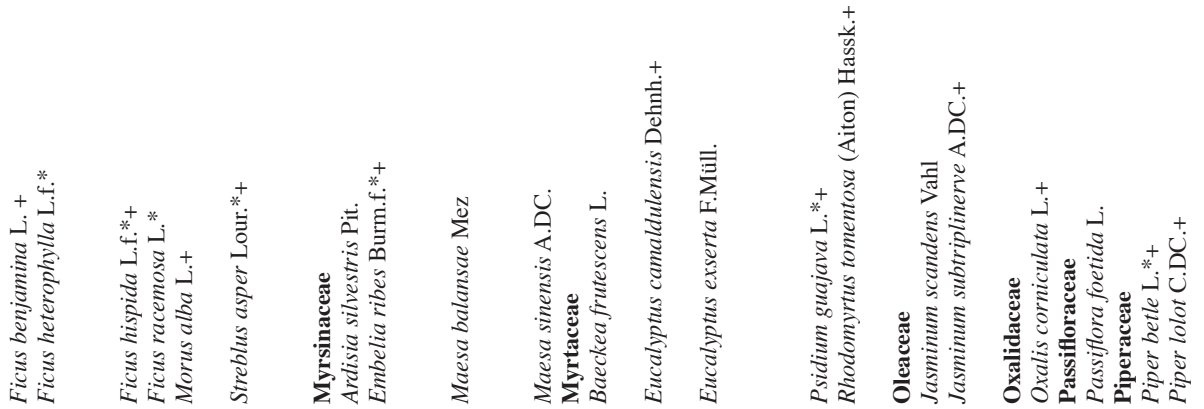




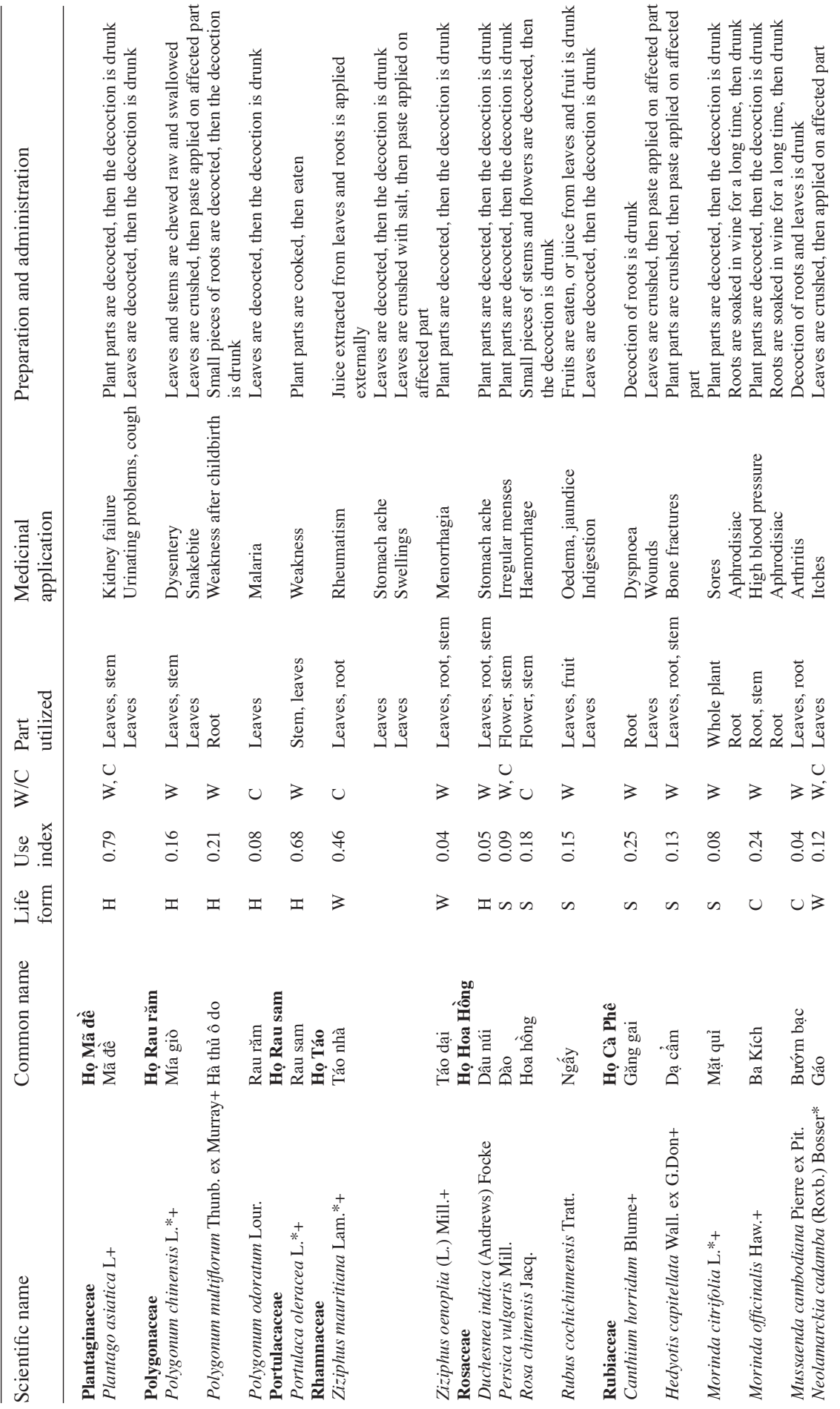




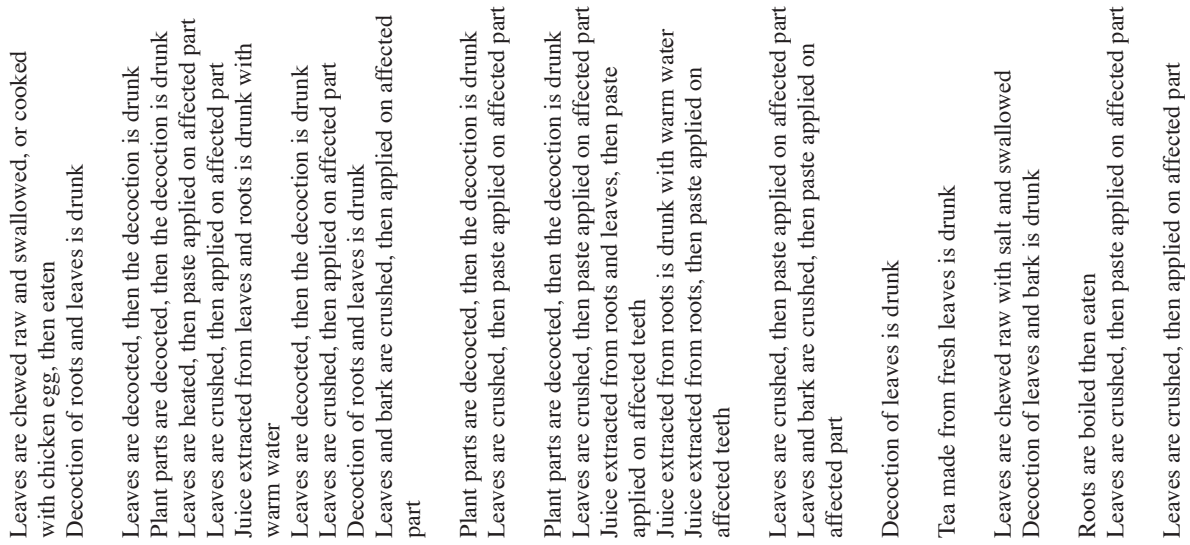

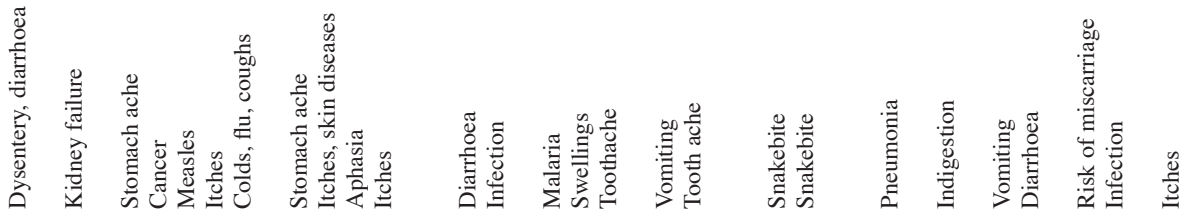

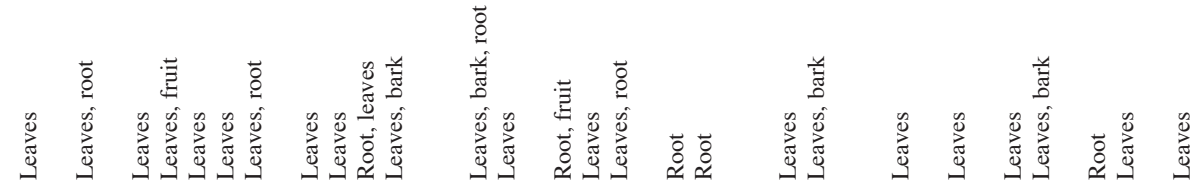

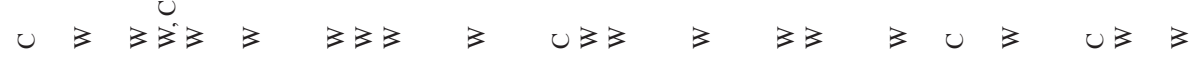


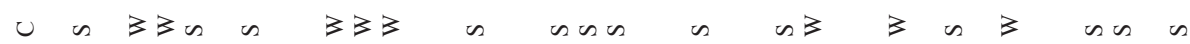

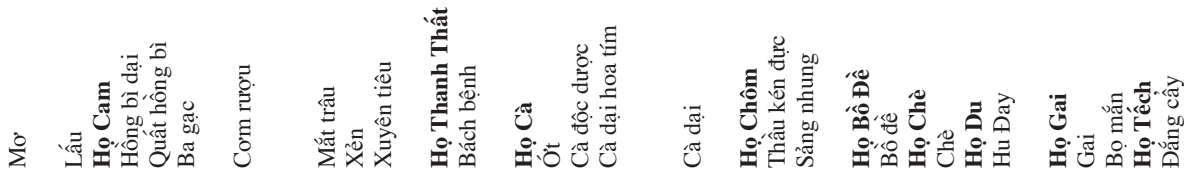

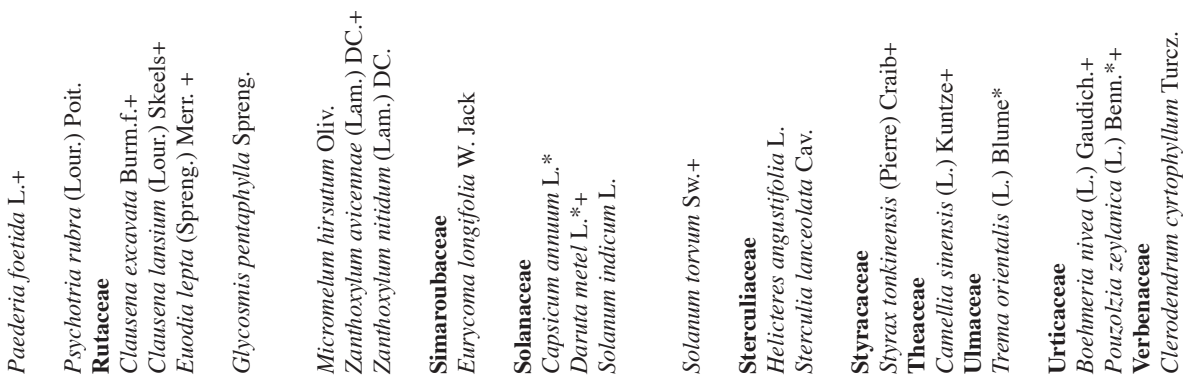




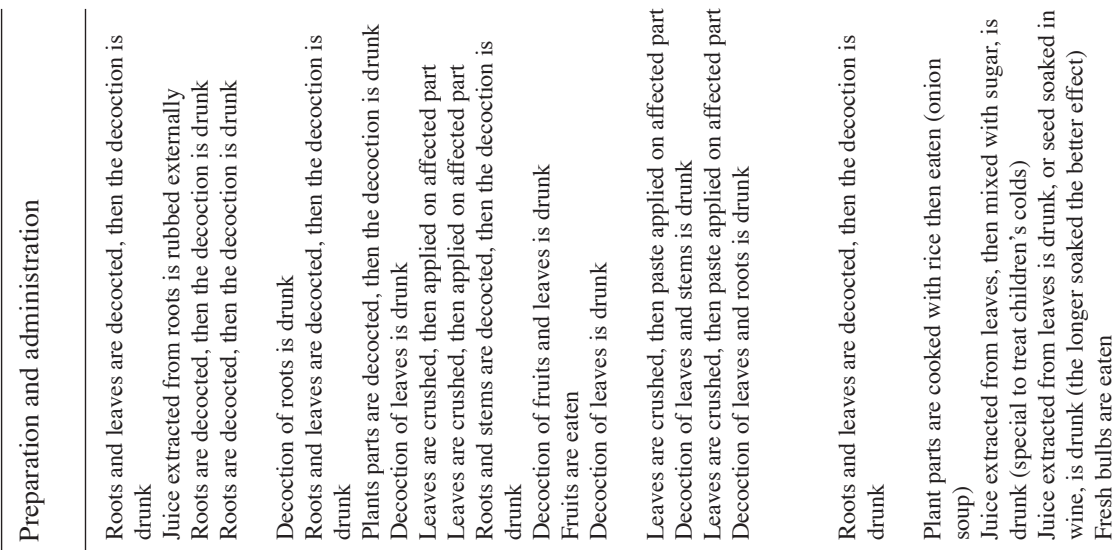

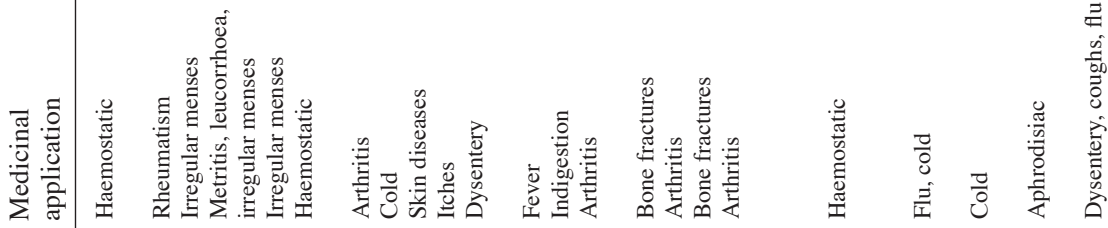

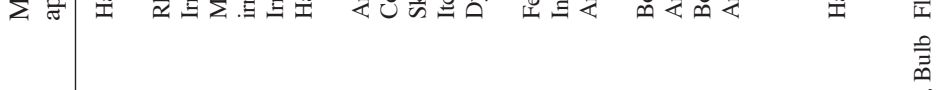

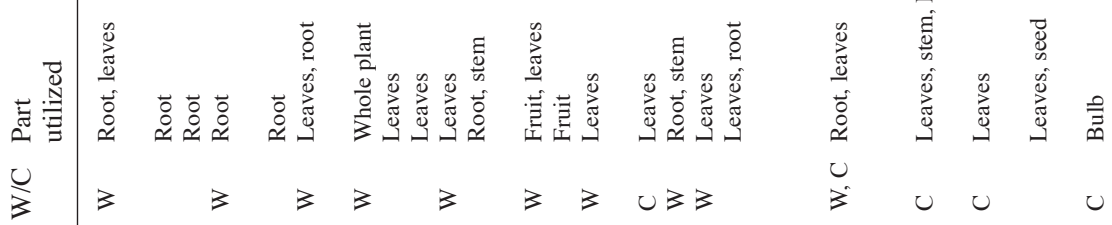

:

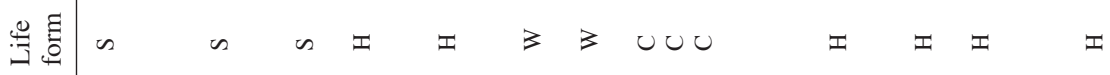

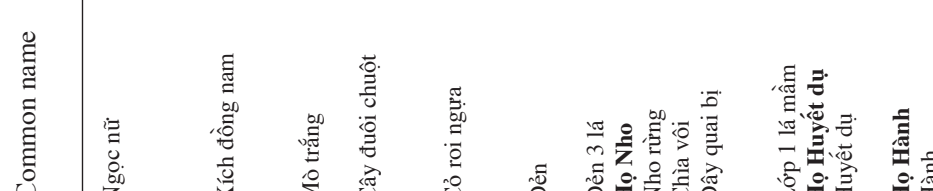

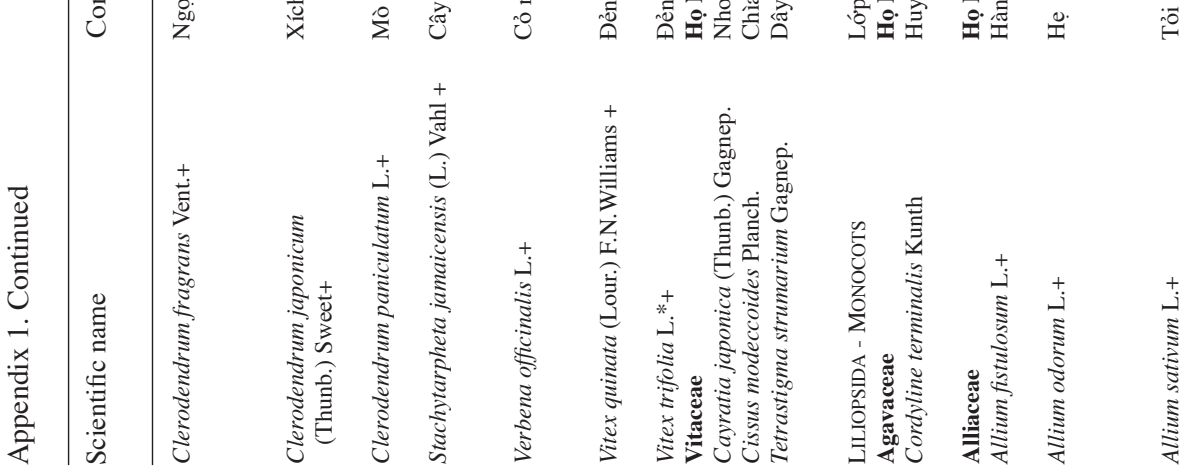




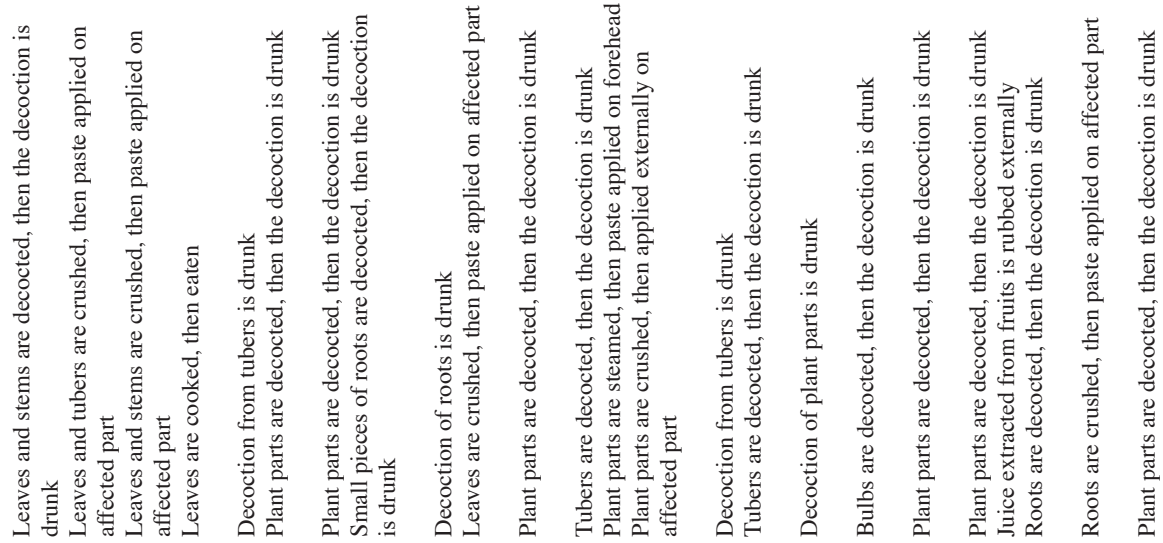

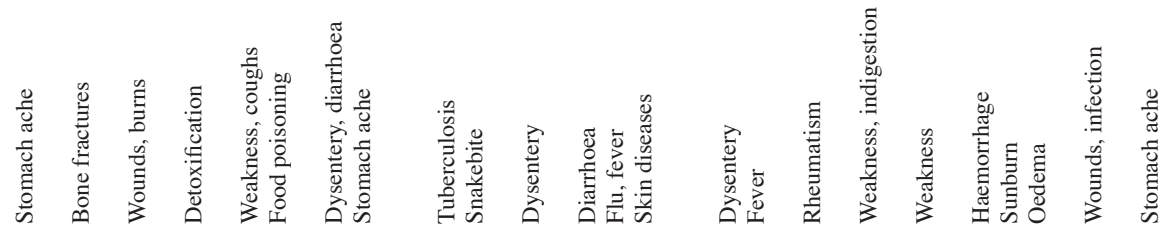

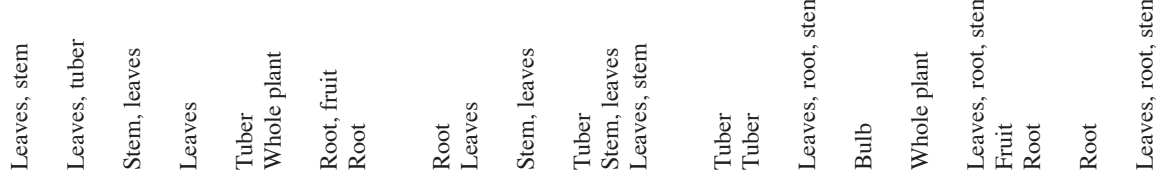

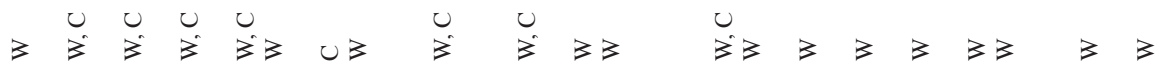

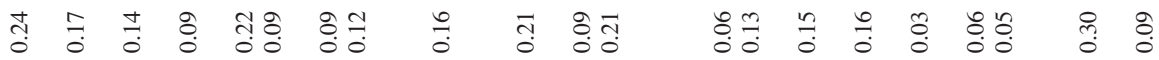

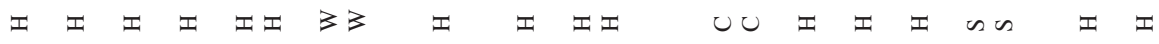

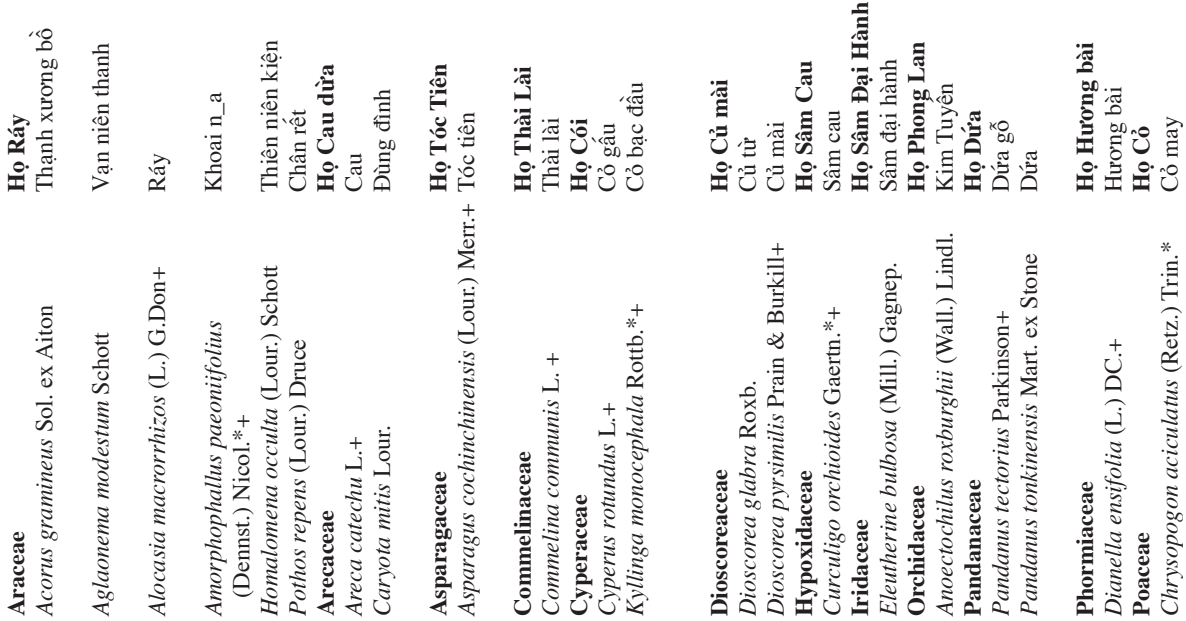




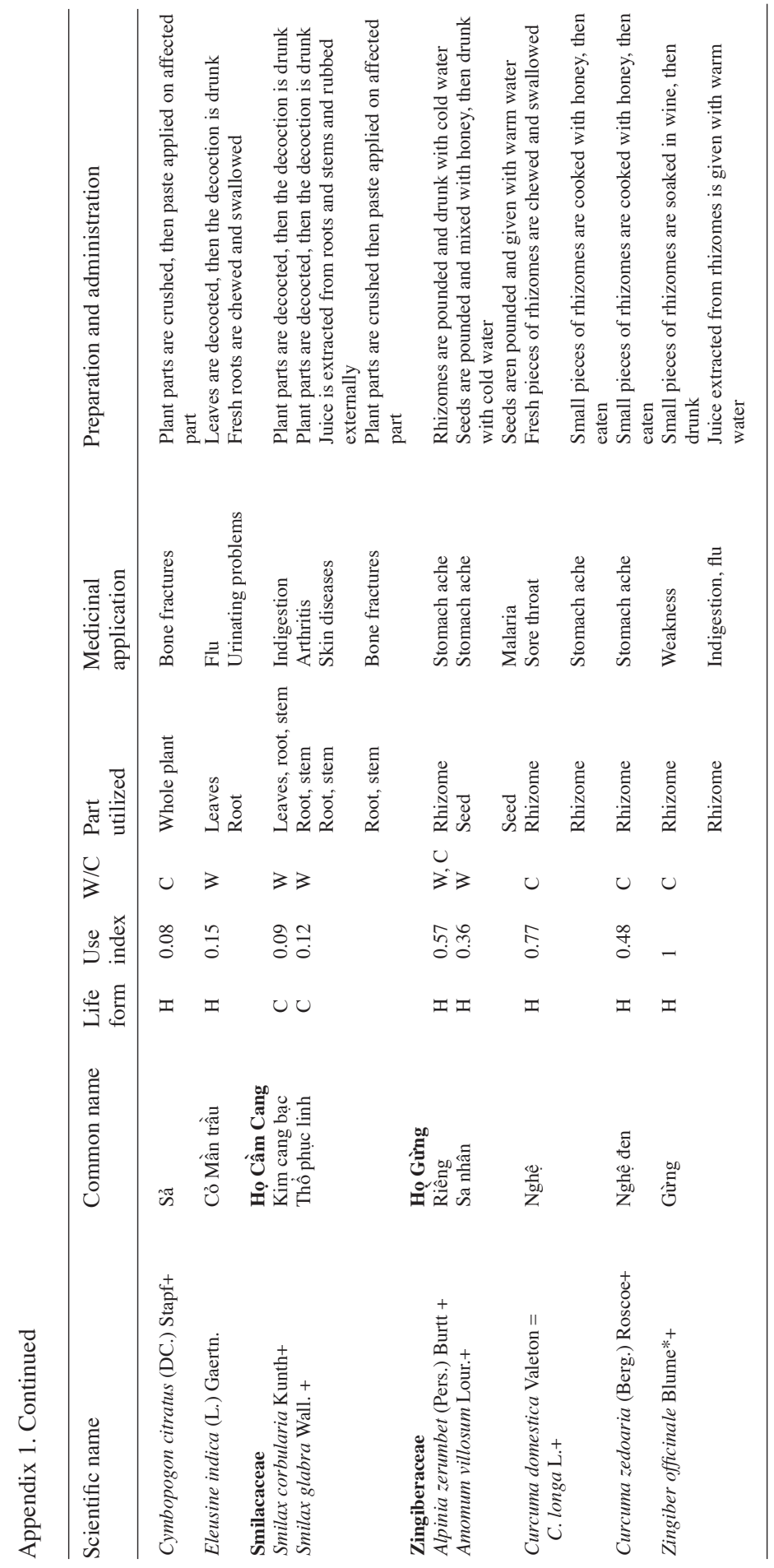


Appendix 2. Commercial medicinal plant species.

\begin{tabular}{|c|c|c|c|c|c|}
\hline Scientific name & Common name & $\begin{array}{l}\text { Abundance } \\
\text { in the wild }\end{array}$ & $\begin{array}{l}\text { Intensity of } \\
\text { collection }\end{array}$ & $\begin{array}{l}\text { Price in US\$ } \\
(1 \$=16.000 \\
\text { Vietnamese dong) }\end{array}$ & $\begin{array}{l}\text { Market } \\
\text { demand }\end{array}$ \\
\hline POLYPODIOPHYTA - FERNS & Ngành Dương xĩ & & & & \\
\hline Dicksoniaceae & Họ Lông cu li & & & & \\
\hline Cibotium barometz (L.) J.Sm. & Lông cu li & Low & Medium & $0.32 / \mathrm{kg}$ dried root & Medium \\
\hline MAGNOLIOPHYTA - ANGIOSPERMS & Ngành Ngọc Lan & & & & \\
\hline MAGNOLIOPSIDA - DICOTS & Lớp 2 lá mầm & & & & \\
\hline Araliaceae & Họ Ngũ ra bì & & & & \\
\hline $\begin{array}{l}\text { Schefflera octophylla (Lour.) Harms } \\
\text { Asclepiadaceae }\end{array}$ & $\begin{array}{l}\text { Chân chim } 8 \text { lá } \\
\text { Ho Hà thủ ô }\end{array}$ & High & Medium & $0.07 / \mathrm{kg}$ fresh leaves & Medium \\
\hline Streptocaulon griffithii Hook.f. & Hà thủ ô & Medium & Medium & Not stable & Medium \\
\hline Asteraceae & Họ Cúc & & & & \\
\hline Gynura japonica (Thunb.) Juel. & Cúc Tam Thất & Medium & Medium & Not stable & Medium \\
\hline Fabaceae & Họ Đậu & & & & \\
\hline Abrus precatorius $\mathrm{L}$. & Cam thảo & Medium & Medium & Not stable & Medium \\
\hline Spatholobus suberectus Dum. & Huyet rong lao & High & High & $0.06 / \mathrm{kg}$ dried stem & High \\
\hline Lauraceae & Họ Long nảo & & & & \\
\hline Cinnamomum cassia Blume & Quế & Low & Low & $0.7 / \mathrm{kg}$ dried bark & Medium \\
\hline Myrsinaceae & Họ Đơn nem & & & & \\
\hline Ardisia silvestris Pit. & Lá khôi & Low & Low & $0.1 / \mathrm{kg}$ fresh leaves & Medium \\
\hline Polygonaceae & Họ Rau răm & & & & \\
\hline Polygonum multiflorum Thunb. ex Murray & Hà thủ ô do & Low & Medium & $0.6 / \mathrm{kg}$ fresh tuber & Medium \\
\hline Rubiaceae & Họ Cà Phê & & & & \\
\hline Morinda officinalis Haw. & Ba Kích & Low & High & $2.5 / \mathrm{kg}$ fresh tuber & High \\
\hline Mussaenda cambodiana Pierre ex Pit. & Bướm bạc & Medium & Medium & Not stable & Low \\
\hline LILIOPSIDA - MONOCOTS & Lớp 1 lá mầm & & & & \\
\hline Alliaceae & Họ Hành & & & & \\
\hline Allium sativum $\mathrm{L}$. & Tỏi & Cultivated & & $0.07 / 4$ tubers & High \\
\hline Araceae & Họ Ráy & & & & \\
\hline Acorus gramineus Aiton et Soland. & Thạnh xương bồ & Medium & Medium & $1.9 / \mathrm{kg}$ dried stem & Low \\
\hline Homalomena occulta (Lour.) Schott & Thiên niên kiện & Medium & Medium & $0.32 / \mathrm{kg}$ dried stem & Medium \\
\hline Smilacaceae & Họ Cầm Cang & & & & \\
\hline Smilax glabra Wall. ex Roxb. & Thổ phục linh & Medium & Medium & Not stable & Medium \\
\hline Zingiberaceae & Họ Gừng & & & & \\
\hline Amomum villosum Lour. & Sa nhân & High & High & $0.6 / \mathrm{kg}$ dried seed & High \\
\hline Curcuma zedoaria (Berg.) Roscoe & Nghệ đen & $\begin{array}{l}\text { Low in wild, } \\
\text { but cultivated }\end{array}$ & Medium & $\begin{array}{l}0.95 / \mathrm{kg} \text { fresh rhi- } \\
\text { zome }\end{array}$ & High \\
\hline Zingiber officinale Blume & Gừng & Cultivated & & $0.7 / \mathrm{kg}$ fresh rhizome & High \\
\hline
\end{tabular}

